\title{
Alexander Chirila
}

Webster University, Thailand

https://doi.org/10.18778/1733-8077.10.4.06

\section{The River That Crosses an Ocean: Ifa/Orisha in the Global Spiritual Marketplace}

Abstract Ifa/Orisha, the traditional spiritual practice of the Yoruba nation, has entered the global spiritual marketplace. With thousands of worshipers on both sides of the Atlantic, practitioners and participants are engaging new arenas of discourse. In southwest Nigeria, storytellers are expressing the living religion through narratives that are relevant, adaptable, and meaningful in a plurality of contexts. From the often antagonistic relationship between Ifa/Orisha and the Abrahamic faiths, to the challenges posed by modernity and globalization, practitioners are renegotiating the identity of their religion in social and philosophical ways. Interpreting data gathered from interviews conducted in Nigeria and the United States, I present a qualitative analysis of how practitioners, participants, and non-practitioners interact with the fundamental premises underlying the matrix of symbols, rites, and narratives that represent traditional Yoruba religion.

Keywords Ifa; Orisha; Yoruba; Ogun; Osun; Nigeria; African Religion and Spirituality

Alexander Chirila is currently an Assistant Professor at Webster University, Thailand. Dr. Chirila received his B.A. from New York University and his M.A. and Ph.D. from the State University at Albany. In 2011, he accepted an academic posting in Nigeria, where he conducted research into the rites and beliefs of Ifa/Orisha practitioners and worshipers. His research interests include comparative symbolism, religion and mysticism, and sacred literature. He is working towards a comprehensive analysis of modern spiritual practices, ranging from spiritual tourism and shamanism, to mys- ticism and syncretism. Blending analytical psychology, qualitative research, and philosophy, he hopes to map patterns in the subcultural practice of spirituality. He is the author of two books: the first a Post-Jungian analysis entitled Manifest Individuation: Comparative Symbolism and Archetypal Progressions in Mark Twain's The Adventures of Huckleberry Finn and Cormac McCarthy's Blood Meridian, and the second a novel entitled True Immortality

email address: symboldreamer@hotmail.com
"This is Osun." The priest said, showing me a stylized brass figurine. "She can move across the Earth at 10,000 $\mathrm{km}$ per second. That is how she can be anywhere in the world, and respond to anyone who prays to her. You know, there are many, many people who pray to Osun."

“Does she hear any language?” I asked.

The priest nodded. "Yes. She is a spirit, you know. She hears what the heart says. It doesn't matter what language you speak."

[personal communication, May 2012]

Twas not the first oyinbo (white man) interested in learning more about the spiritual practices of the Yoruba in southwest Nigeria. My first challenge was to penetrate a layered and complex matrix of social responses designed to protect and maintain the integrity of an indigenous esoteric tradition. It is not uncommon for practitioners of Ifa and Orisha to mislead foreigners, taking advantage of a new paradigm of spiritual tourism between the West and developing countries around the world. ${ }^{1}$

On account of its popularity in the Diaspora, particularly in Cuba and Brazil, as well as in the United States, the Yoruba spiritual tradition and pantheon attracts a good deal of attention. While spiritual tourism is not as prevalent in Nigeria as it is in Peru or Thailand, the annual Osun Festival in Oshogbo draws hundreds of visitors from around

${ }^{1}$ I was told, on several occasions by different individuals, "Be grateful that you know someone. Otherwise, they would have done something useless and taken your money You would never have known the difference." I asked whether this happens often. "It happens. Foreigners come here with money." the world. ${ }^{2}$ While many visitors are familiar with Ifa and Orisha, there are many different practices, interpretations, and representations.

A comprehensive and comparative survey of the various traditions that incorporate and employ elements of West African Ifa/Orisha would be lengthy indeed. Suffice it to say that worshippers in Cuba are not identical in their practice to worshippers in New York, and neither are identical in their practices to worshippers in southwest Nigeria. Nonetheless, the Orishas are considered to be the same spirits regardless of whether they are invoked in Yoruba, Creole, Spanish, Portuguese, or English. It is possible to ascribe the transnational character of Yoruba religion to the historical circumstances surrounding its proliferation. Its currently international identity, however, suggests that Ifa/Orisha is meaningful and relevant to a broad spectrum of participants. This is remarkable for an indigenous religious tradition, in part because Ifa/Orisha is closely tied to the Orishas and the rites meant to elicit their protection and aid, or to prevent them from harming an individual or group. Ifa/Orisha is polytheistic, worldly, often uninhibited, unpredictable, and radically diverse. It emphasizes difference and plurality, maintaining integrity both esoterically and exoterically through carefully moderated relationships between practitioners and participants.

${ }^{2}$ Peter Probst writes (2004:34-35): "[w]hat has taken place is the transformation of a formerly 'local' festival into a 'globand attended by visitors from all over the world...many of the tourists attending are members of the African Diaspora in Europe, the U.S., the Caribbean, and South America, who come to Nigeria either to find or to revitalize their ethnic identity." 
I was curious to learn how Nigerian practitioners and participants acknowledge the global character of Ifa/Orisha. Do they engage the religion as a root system of local or regional origin; or as an inclusive system able to assimilate religious and magical elements from practices external to Nigeria? I would, of course, let the respondents speak for themselves. Many of them were, after all, the representatives and storytellers of a tradition that originated in their homeland.

I conducted interviews with over forty respondents. ${ }^{3}$ Interviews were conducted in a number of locations throughout southwest Nigeria, including Ile-Ife, Oshogbo, and Ibadan; as well as in Yola-Jimeta, Adamawa State. I arranged interviews in Yorubaland through a sponsor, ${ }^{4}$ and after several structured interviews, I was invited to observe and participate in a sequence of Ifa/Orisha ceremonies over the course of the next two years. I conducted interviews with practitioners, including Ifa priests, as well as priests in the service of Osun, Shango, and Ogun, and apprentices undergoing training to become professional babalawo. I also conducted interviews with Yoruba, Igbo, and Hausa respondents of varying ages and professions, from university students to okada drivers; as well as non-African respondents from the United

${ }^{3}$ Most interviews were one-on-one, but on several occasions included other individuals. In some cases, an interview would begin with a single individual and expand as others arrived who became interested in contributing information. There were a number of structured interviews with several individuals, including a meeting with two priests and an apprentice tasked with

${ }^{4} \mathrm{I}$ am indebted to my sponsor for facilitating a good deal of my primary research among practitioners and worshippers in ain that this oyinbo was given access to genuine information and experience.
States, Haiti, and Columbia. Questions focused on familiarity with Ifa/Orisha in terms of practice and philosophy, as well as respondents' personal and family history related to Yoruba religion; belief and relationship to the symbols and concepts of Ifa/ Orisha; knowledge of related variations of African spirituality. Many interviews were spontaneous and unstructured, serendipitous occasions of right time and place-including a meeting with a local king and his royal Ifa priest. $^{5}$

Understandably, practitioner engagements were varied. A pattern did emerge, however: practitioners who lived in larger urban centers were more familiar with external interpretations, as well as foreign practitioners and initiates. Consequently, they were either prepared to, or proficient in, adapting their explanations to accommodate multiple perspectives and interpretations. In doing so, they perform a complex narrative function: they draw from disparate frames (i.e., local, tribal, and global), incorporating different interpretations (of the Orishas, ritual objects, and mythology), different mediums of representation (music, art, performance), and interrelate these frames, interpretations, and representations into a sacred space created in the moment to suit a specific, worldly purpose. At the same time, they draw from specific, lineage-based stocks of knowledge anchored in familiar, socially reinforced conventions that satisfy a real need for a meaningful and effectual exchange between practitioner and

${ }_{5}^{5}$ On this particular occasion, I was interested in learning more about local rural practice outside of Ile-Ife, specifically spirit. Fortuitously, my sponsor's father was from a complex spirit. Fortuitously, my sponsor's father was from a complex
of villages northwest of Oshogbo, and he was able to make formal arrangements for a meeting with the king. participant(s). In contrast, practitioners outside of larger urban centers were more likely to rely solely on lineage-based, directly transmitted forms. Unfortunately, for local practitioners who do not have access to, proficiency in, or an interest in engaging foreign importations of Ifa/Orisha, they are faced with a diminishing matrix of local interest and investment. Young men and women from the villages are seeking their fortunes in the rapidly growing cities throughout Nigeria, encountering highly aggressive congregations of Christians and Muslims, as well as a marked emphasis in modernity, industrialization, and globalization. The religious systems of the largely uneducated elders do not hold so strongly, and are eroded steadily. Diminished forms may exist, even those that may have been distorted by the pressures of social change.

Practitioners of Ifa/Orisha, as well as participants (clients, witnesses, etc.) enact the roles of storyteller: clients petition the priests with the troubles of their daily lives, opening connections into multiple arenas of human engagement. The priest (babalawo) surrounds, or encases the exchange in sacred space, ensuring that a very specific meaning (or range of meanings) is assigned to the actions, words, and objective of the consultation. Stories are told that serve as invocations (rites of summoning), reference-points (applying the principle of sympathetic magic ${ }^{6}$ ),

${ }^{6}$ Marcel Mauss (2001:69) writes: “[a]mongst [mythical spells] we have a type of incantation which describes a situation similar to that which the magician is trying to produce. The description usually involves a fairy story or an epic tale, with heroic or divine characters....the reason behind it being some-
thing like this: if a certain person (a god, saint, or hero) was able to do such and such a thing (usually a very difficult task) in such and such a circumstance, perhaps he could perform the same feat in the present case." Mauss's definition is applicable here. predictions/divinations, and positive and/or negative exhortations. ${ }^{7}$ This contextual blending of multiple frames is then distilled into a meaningful correlation by the practitioner, who empowers the supplicant or client to continue the narrative. New stories are constantly told, building and reinforcing connections to pluripotent prisms of association, symbol, mythos, and ritual.

My analysis here will focus on data from respondents representing practitioners, participants, and non-practitioners. ${ }^{8}$ Sandra T. Barnes ${ }^{9}$ (1997:20) presents a useful methodology for engaging Ifal Orisha that "focuses on cultural representations by hovering between two levels of analysis: one that stays close to the empirical ground, as does ethnoscience, and another that soars to the language of universal principles such as deep structures of the mind, as does structuralism." These universal principles, or "root metaphors," are abstractions "formulated by the minds that are being explored...because it is created by the actors, the generalization retains its cultural uniqueness. But because it is an abstraction, it lends itself to being translated from the terms of one culture to another" (Barnes 1997:20).

${ }^{7}$ In his analysis of ritual conduct, Emile Durkheim (1995) identifies two aspects to every cult: negative and positive. In short, the negative cult is associated with prohibition and taboo, and the positive cult with sacrifice: "[a]nd so when men feel there is something outside themselves that is reborn, forces that are reanimated, and a life that
(Durkheim 1995:352-353).

${ }^{8}$ The data substantiating this article is based on interviews conducted between 2011 and 2013 with practitioners (a priest and non-practitioners (Yoruba, Hausa, and Igbo Nigerians, as well as Westerners).

9
Tarly anefulytical method described by Barnes (1997) is particumetaphor, emphatic symbol, root paradigm, and archetype. 
It may also be helpful to make reference here to the ethnographic model proposed by Robert Prus (1997:17): "the interactionist approach or paradigm attends centrally to the study of human lived experience as the paramount reality...the most feasible way of learning about human lived experience is through interactive inquiry into human life-worlds." Ifa/Orisha, though active in countless different lifeworlds on both sides of the Atlantic, is nevertheless strongly tied to its roots in West Africa. Its cohesion and adaptability is strengthened by the relevance and meaning ascribed to the social and private role of the religion by practitioners and non-practitioners alike.

I am not unaware that morphologies of religion have been imposed on accounts and studies of African traditions. James L. Cox (2001:351) rightly points out in a criticism of McKenzie's Hail Orisha! that "phenomenological typologies, understood as essential characteristics of religion, fail to acknowledge the historical, social, and cultural contexts out of which they developed. Typologies only make sense as pragmatic, limited terms to help facilitate communication and promote understanding. ${ }^{\prime 10}$ Cox's point is not dissimilar to Emile Durkheim's position (1995:91): "social facts exist in relationship with the social system to which they belong; hence they cannot be understood apart from it. This is why two facts belonging to two different societies cannot be fruitfully compared simply because they resemble one

${ }^{10}$ Cox (2001:351) goes on to say that "it is important for scholars to adopt self-reflexive approaches whereby they position their investigations." another."11 Ifa/Orisha is far removed from the totemic religions posited by Durkheim as the most basic and universal form of religious belief and practice. ${ }^{12}$ However, different varieties of practice exist concurrently that appear to retain elements of varying stages in the development of the religion. Granted, many of these expressions are the result of factors that affect uprooted and transposed native traditions.

It should be noted that, at this time in history, the primarily oral traditions of Yoruba spirituality have been considerably influenced by tension, syncretism, and globalization, rendering any attempt to reconstruct an original Ifa/Orisha model all but impossible. ${ }^{13}$ The same adaptability that allows the tradition and its components to survive in so many different forms also precludes a definitive version, while allowing a plurality of narratives to exist in the same arena. There are many ${ }^{11}$ Durkheim himself does posit a series of religious stages of de-
velopment, classifying later stages as more developed than others, more primitive varieties. For Durkheim, the totemic conceptual scheme gives way to higher levels of differentiation, specialization, and anthropomorphizing tendencies. Among the higher stages of development is the inclusion of a supreme creator deity, which Durkheim suggests is a natural (as opposed to strictly in-

${ }^{12}$ Durkheim sourced his information in an admirable collection of ethnographic accounts, including, of course, Frazer'
The Golden Bough. Durkheim's primary focus, however, was The Golden Bough. Durkheim's primary focus, however, was
on the Aborigine tribes of Australia. He considered the prac tices described by Spencer and Gillen, Strehlow, and Howi to be "the most favorable terrain for the study of totemism" (Durkheim 1995:88-90)

${ }^{13}$ For example, one respondent referred to guns in a retelling of Ogun's origins and initial interactions with humankind. Obviously, guns were introduced to West Africa well after the Iron Age, considered by most scholars to coincide with the widespread generation of Ogun cults throughout could only tell me that "most of the old, old stories have been forgotten or lost. Sometimes, they are the same, except we say 'machetes' instead of 'guns'" (personal communication, May 2012). practicing babalawos in the Yoruba nation presently, but there are fewer initiates today when compared to the precolonial heyday of the itinerant diviner. Ifa/Orisha is by no means an endangered tradition. ${ }^{14}$ However, it is equally safe to say that, inasmuch as Yoruba spirituality is syncretic, there are relatively few examples of unadulterated practice, particularly with respect to the lesser-known deities. There is little doubt that for as many religious elements as have survived the long years between pre-contact and modern Africa, there are many more that have been utterly forgotten. There are deities who will never again receive the sacrifices of their worshippers.

Nonetheless, there is no indigenous move to create a definitive version. Rather, the preservation of efficacious rites is entrusted to direct transmission (personal communication, December 2011), while the flexibility of the system itself is expected to accommodate the integration of new ideas and interpretations. Moreover, multiple narratives exist explaining or addressing the same idea or complex of ideas (Orunmila's relationship to Osun, for example). Some of these may have been generated among different narrative groups at the same time, while others are clearly revisions of earlier stories. The motives for these revisions are many, including the integration of new objects or ideas and the assignment of spiritual symbols and meaning to them. Nevertheless, both the earlier and later nar-

${ }^{14}$ I do not mean to suggest that Ifa/Orisha is a singular, homog-
enous tradition in Nigeria, elsewhere in West Africa, or in the
Diaspora. There are remarkable similarities across the board,
but the differences are notable, as well as culturally and his-
torically meaningful. A difference in the number of cowries
used in divination, for example, may indicate differences in the
underlying mythology.

${ }^{14}$ I do not mean to suggest that Ifa/Orisha is a singular, homog-
enous tradition in Nigeria, elsewhere in West Africa, or in the Diaspora. There are remarkable similarities across the board, torically meaningful. A difference in the number of cowries underlying mythology. ratives continue to exist, suggesting that different variations of Ifa/Orisha can survive concurrently. Their continued survival is, of course, dependent on social investment, ${ }^{15}$ and it has become apparent to many practitioners that, in order to preserve the rites themselves (including the consecration of ritual tools, invocation of the Orishas and Odu, etc.), a broader range of transmission should be adopted.

Practitioners of Ifa/Orisha in southwest Nigeria incorporate belief in the ubiquitous power Durkheim called the totemic principle ${ }^{16}$ known to the Yoruba as ase; an extensive pantheon of gods and goddesses; and a supreme creator deity (Oludumare). The art, poetry, and dance forms associated with the tradition are varied and expressive of highly adaptive and progressive styles. Practitioners also exhibit a willingness to explain the ritualistic and symbolic relationships that constitute religious observation in public and private. Durkheim (1995:134-135) identified mythology as an a posteriori creation designed to explain highly emotional correlations based on collective experience. I am in no position to determine whether or not ase preceded the corpus of myths and narratives that continue to be told, adapted, and translated. However, it seems that ase retains its impersonal, causal integrity as a collective, social energy that is nonetheless harnessed in varying degrees by the individual in pursuit of

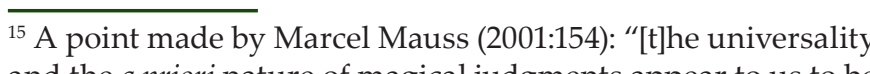
and the a priori nature of magical judgments appear to us to be the sign of their collective origin."

${ }^{16}$ Durkheim (1995:207) writes: “[t]he central notion of totemism is that of a quasi-divine principle that is immanent in certain animal or plant." Durkheim goes on to say that this principle is the clan itself, the power of the collective overpowering the sensibilities of the individual and instigating a process of ideation that expresses itself in totemic, ritualistic ways. 
personal goals. Symbolic relations, natural phenomena, circumstantial events, and a range of both individual and human experiences are linked to the involvement of the Orishas and lesser spirits, ancestors, and unnamed natural entities that act and react through interconnected human worlds. Participants in these worlds carefully negotiate personal and collective interpretations to maintain the chain of meanings that correlate tangible experiences to spiritual or supernatural origins. In many respondents, this attribution was clearly automatic. Higher degrees of involvement correspondently featured a tendency to ascribe spiritual causes to daily events (encountering a particular individual or acquaintance, the arising of an opportunity or obstacle, etc.). ${ }^{17}$ In many cases, these interpretations are quite clever. In one case, the purchase of a shoddy used car that broke down at a very inconvenient time (on the road from Okene to Ile-Ife) was ascribed to the trickery of Esu working alongside Ogun-one a spirit of mischief and misfortune, the other a spirit of iron and industry (personal communication, May 2012).

Ifa/Orisha occupies a range of positions in many lives around the world. For some, it represents a central focus; as priests or active practitioners, they may identify their social roles as representatives of certain lineages associated with specific temples, sites, and deities; or in terms of their social roles as the community's consultants, healers, and protectors. For others, it is marginal, liminal, shrouded in sensationalized superstition. There are many points of interaction,

17 Prus (1997:59) writes: "[s]ubcultures may be most notably defined by activities, but the life-worlds that develop around
these activities are also characterized by sets of perspectives, identities, relationships, commitments, emotional expressions, and linguistic influences." and Ifa/Orisha is constantly rewoven into a radically changing landscape. Storytellers are challenged to preserve the essence of the system while maintaining their own roles as narrative agents. The substance of the belief system must be refreshed within competing life-worlds that are both culturally internal, and as far afield from their historical source as the metropolises of the New World. The balance between multiple expressions and a socially constructed, independent unity of interwoven narratives is a fine one, and difficult to maintain.

The major Orishas are well-known and can be found under a variety of names in sources ranging from scholarly articles to mass-market New Age catalogues of deities and spirits. In South America, they are most commonly syncretized with Catholic saints for a variety of reasons, but such conflations are misleading to outsiders and non-practitioners. This is often intentional, as Sheila S. Walker (1980:32) writes: "[w]hereas some people did indeed become Catholic, many managed to remain faithful to their ancestral religion, while avoiding persecution by superficially catholicizing their deities, a practice to which Catholicism lends itself well."

In Nigeria, this type of syncretism is less common than in the Diaspora. Evangelical Christianity does not emphasize the reverence of saints or intermediaries; nor does the Yoruba concept of distant Oludumare accord with the Protestant vision of a personal relationship with God..$^{18}$ Indeed, many of the Yoru-

${ }^{18}$ Interestingly, however, a type of African spirituality-ProtesMitchell (1975) in saying that: "[b]eing filled with the Holy Spiri resembles possession by the Loa in the Vodou religion an a kind of Protestant-Vodou syncretism exists" (Walker 1980:34). ba Orishas are earthbound spirits. Islam, of course, maintains a distinctly antagonistic stance towards idolatry. Still, there are many adherents of Yoruba spirituality who identify as Christian or Muslim, and it is not unknown for an individual belonging to another religion to consult a babalawo. In fact, many practitioners in Nigeria and in the Americas hold two faiths, freely blending symbolic and ritual elements in an endless variety of ways.

While most, if not all, ethnic groups practiced traditional/indigenous religion and medicine at one time, the spread of Christianity in the South along the coast and Islam in the North across the Sahel greatly diminished the number of active practitioners and limited the application of $j u j u^{19}$ to herbs, charms, and talismans, typically used to ward off danger or encourage success. Even these remnants of a more widespread array of practices are eroding, succumbing to a vigorous campaign of proselytizing by orthodox or fundamental expressions of the two major religions. ${ }^{20}$

The situation is not the same across the Atlantic. Yoruba spiritual traditions are quite healthy throughout South America, as well as in large ur-

${ }_{19}$ This term is commonly employed by Nigerians; however, it should be noted that juju refers predominantly to talismans, amulets, and charms, and is associated with witchcraft.
According to the Oxford English Dictionary, the word itself is According to the Oxford English Dictionary, the word itself is
likely a borrowing from the French joujou, "toy." Yoruba divination and spirituality, although often grouped alongside witchcraft by outsiders, is another matter entirely.

${ }^{20}$ Probst (2004:37) writes: "[t]hough the victory over Fulani did not stop the expansion of Islam, Osun was able to maintain its integrative function. With the advent of Christianity, however, the situation changed...the missionaries made it clear that of an increasing dominance of British colonial rule, their efforts turned out to be successful, and in the early 1930 s, roughforts turned out to be successful, and in the early 1930 s, roughking to give up his office as the chief priest of the Osun cult." ban centers across the U.S., and they continue to gain followers from all walks of life. Many communities that practice these traditions are in contact with their counterparts in West Africa, ${ }^{21}$ and the movement of ideas, styles, and symbols has adopted a new pattern of transatlantic exchange. Enjoying the patronage of scholars, affluent worshipers, and large sectors of urban populations throughout the Caribbean and Americas, as well as a vigorous dynamic of syncretism and diffusion, Yoruba traditions are now returning to their homelands invigorated by a variety of spiritual globalization.

The Ifa Corpus is an oral one, and it is only relatively recently that the verses associated with the 256 Odu (spirits of divination) have been transcribed (see: Bascom 1969; 1980; Abimbola 1976; 1977; Eleburuibon 1989; 1998; 2004; Fama 1994). Moreover, while the structure of an Odu sequence is uniform, individual practitioners are free to express and interpret the verses in their own ways, authorized to do so in accordance with the lineage of their instruction and practice. Amherd (2010:40) writes: "[b]ecause attention and privilege is given to the performance's function in a given context together with its intertextual liability, static repetition is neither sought nor valued. Instead, pleasure and relevance are found in ongoing emergent utterances that make use of orature materials appropriate to the function at hand." No two recitations are going to be exactly alike. During the consultation, the petitioner and practitioner become actors in a sacred

${ }^{21}$ Including the Oyo Tunji settlement in Shelton, South Carolina a neo-Yoruba community dedicated to the traditional worship of the Orishas. Oyo Tunji, according to Walker (1980:36), can be translated as "Oyo Rises Again/is Reborn." Oyo was th once-capital of the West African empire of the same name. 
space exceptional to that context and situation. While the methods of creating this space are conventional and reproducible, there are many factors that converge to facilitate an interaction that is consecrated, unique, and immediately relevant.

Robert Prus (1997:69) writes: “[w]hile the existence of a generally shared language enables the development of any particular subculture, it is important to acknowledge that each set of activities in which people engage represents a realm around which extensions or variants of that linguistic base may be developed." In this case, the language is the matrix of symbols, ideas, and mythological narratives that comprise shared interpretations of Ifa/Orisha, unique to highly diverse cultural, social, and geographic settings. Each engagement works within and from this matrix, but participants are both licensed and encouraged to formulate additional meanings and contextualized interpretations within sacred space.

Naturally, beyond these realms of engagement, outside consecrated space, the system is immediately subject to the imaginative retooling of profane discourse. Different storytellers can choose to address issues or interpretations that may affect their practice or engagement with Ifa/Orisha. On the other hand, collective acceptance of new interpretations or representations depends on a complex process of mutual negotiations that are validated through symbolic reinforcement, appraisals of intention and authority, and consensus. My own interest in learning more about Ifa/Orisha was very carefully evaluated by sponsors and contacts in Yorubaland. Following several divination rites intended to elicit the consent of the Orishas, I awaited the decision of several practitioners in the community as to whether or not I would be admitted into their confidence. I am fortunate that the Orishas looked favorably on my petition, and as well that my intentions were deemed sufficiently genuine by those who are regarded as the guardians of a precious cultural heritage.

\section{Perspectives and Engagements}

It may be helpful to begin this part of the analysis from "outside" the practice. Prus (1997:73) writes: "[t]he objectification process also becomes intensified when outsiders (intentionally or otherwise) engage in 'identity work' pertaining to...interests (curiosities, fascinations, entertainment, knowledge, fear, condemnation, control, elimination) with respect to the subculture in question...they may be seen to contribute to the 'realism' of particular subcultural essences." Rather than relying on the indigenous/foreigner dichotomy, I have opted for a practitioner/non-practitioner framework. Beginning with the non-practitioner, I suggest two primary viewpoints. The first is:

1. The non-practitioner unfamiliar with more than the superficial elements of Ifa/Orisha.

There are significant differences in how this viewpoint is expressed or articulated across cultural and/or national groups. Degrees of familiarity are directly related to exposure. In areas that include a significant number of active practitioners (engaged in visible and public expressions of worship), even those unfamiliar with African spirituality may recognize certain symbols, representations, and other elements. ${ }^{22}$ A citizen of New York or New Orleans, for example, may frequently come across shrines, botanicas, and popular representations of the Orishas. In Haiti, the lwa are well-known even by non-practitioners, as well as in Brazil where Umbanda is as familiar as Catholicism. ${ }^{23}$ In these communities, there are relatively few individuals genuinely unfamiliar with traditions influenced by Yoruba spirituality. The citizen of a community that is strictly Christian may never have seen anything beyond a Voodoo horror film. To clarify, unfamiliar in this case refers to those who have had a relatively low level of exposure, and are non-participants, as well as non-practitioners. The difference is that an individual may be a participant without engaging in practice of any kind, including worship, sacrifice, or ritual. ${ }^{24}$

In areas of low exposure, communities that practice sustained engagement with Ifa/Orisha are rarely, if ever, encountered. Individuals and groups unfamiliar with African religions are more vulnerable to specific channels of representative ideation (churches, television, film, etc.) and more likely to express

${ }^{22}$ Prus would likely characterize Ifa/Orisha as transnational and transsocietal, as well as encompassing "virtually all areas of transsocietal, as well as encompassing "virtually all areas of
participants' lives" (1997:45). Participants may engage in "cycliparticipants "lives" (1997:45). Participants may engage in "ycli-
cal" or "occasional subcultural phenomena," depending on the extent of their involvement and role. Even priests or babalawo may engage in other life-worlds that only marginally involve the religion, fully engaging their function only during ceremonies, consultations, and similar activities.

${ }^{23}$ Sandra T. Barnes (1997:17) writes: “Umbanda is the main beneficiary of an outpouring of books, conferences, and theologithereby systematize and legitimate this faith in ways that are characteristic of world religions. In the process, Umbanda has become a national religion that embraces racially mixed congregations."

${ }^{24}$ Researchers are most certainly participants. Prus (1997:224) writes, "[e]thnographic research is not only an interpretive, cooperative, and interactive process, but it is also a mutual process." or recognize negative associations (occultism, black magic, superstition, the reanimated dead, etc.). Where Ifa/Orisha is scarce or absent-particularly outside of Nigeria-the representatives and storytellers of the religion cannot defend their own interpretations and expressions, reassign unfavorable meanings, or "deal with outsiders" (Prus 1997:138) in constructive ways.

2. The non-practitioner familiar with Ifa/Orisha.

This viewpoint is found among the Yoruba, as well as Africans and non-Africans familiar with Ifa, Candomblé, Santeria, Umbanda, Vodun, Spiritismo, et cetera. Scholars who study the traditions or those who go to observe a ceremony are examples of participants who are not only recipients of traditional narratives but in some way contribute to their proliferation. In terms of exposure, participant non-practitioners do not rely on stereotypes or media representations, but are knowledgeable in at least several dimensions of Yoruba spirituality, including the Orishas and their representations, even the symbols and powers associated with them; the history of the religion; and the purpose of many rituals, including the much maligned "mounting," or spirit possession. ${ }^{25}$ This group may be characterized by acceptance or tolerance $^{26}$; however, this is not always the case: "[u]ntil the latter part of the 1960s, the Catholic influence was so prevalent in the dominant culture ${ }^{25}$ For a good account of spirit possession and how it is perceived by non-practitioners, as well as the importance of this
element to African spirituality and religion, see: Walker (1980). ${ }^{26}$ Michael A. Nicklas (1990:96) writes: “Imlass culture in Brazil ${ }^{26}$ Michael A. Nicklas (1990:96) writes: "[m]ass culture in Brazil
can be characterized by acceptance and embracing of this can be characterized by acceptance and embracing of this
emerging culture. It is estimated that there are roughly 300,000 Afro-Brazilian groups in Brazil." 
that the Afro-Brazilian groups, including Umban$\mathrm{da}$, were thought not to represent a religion" (Nicklas 1990:91). Instead, they were considered ethnic cult groups, characterized by a certain insularity described by Walker (1980:32): "[t]he purpose for keeping slaves from the same group together was not humanitarian in inspiration. On the contrary, the rationale was that such a practice should insure that slaves from different groups remain conscious of their own specific ethnic identity." The insularity that preserved Yoruba identity and tradition also slowed the process of social integration that would eventually result in the creation of Umbanda. Still, as entrenched paradigms of dominance and subordination give way to new patterns of social exchange and globalization, the insularity that formerly characterized religions like Candomblé or Haitian Vodun are giving way to new models of practice that may boast larger spheres of cultural influence.

In exchange, however, there is the contention that a high degree of syncretism endangers the authenticity of a given system. Lindsay Hale (2001) writes:

Diana Brown (1994) and Renato Ortiz (1978) both present compelling histories of how the founders of Umbanda sought to systematically strip the Afro-Brazilian religious traditions found in turn-of-the-century Rio de Janeiro of those elements-such as blood sacrifice, "lewd" dancing, consumption of alcohol, "black magic," and sexual exploitation-offensive to bourgeois sensibilities. (p. 218)

As Walker points out in her article, many of those very elements are essential to African traditional practices. Not only is spirit possession considered central to many disciplines, ${ }^{27}$ most notably Vodun, the Ifa Corpus makes it abundantly clear that sacrifice is the primary locus of exchange between the mortal and supernatural worlds. ${ }^{28}$

Perhaps the most significant element that affects outsiders' appraisal of Yoruba practice is animal sacrifice-indeed, the emphasis on sacrifice in general. Human sacrifice is forbidden, of course, and there is an $O d u$ verse that explains why, ${ }^{29}$ but the practice is nonetheless often attributed to African traditional religions. One respondent, a practitioner of traditional Peruvian shamanism, specifically Ayahuasca, expressed this view of African practices: "Working with any spirits that require blood sacrifice is dangerous. The intentions of the practitioner may be good, but spilling blood in exchange for power is black magic; the intentions no longer matter. That kind of practice is corruptive" (personal communication, November 2012). These qualms are more often expressed by Westerners and spiritual tourists, however. While the blood and certain organs are offered as part of an $e b o$, the rest of the animal

27 Margaret Thompson Drewal (1997:207) writes: "[s]pirit mediumship is the most significant role of a priest." Similarly, Walker (1980:28) writes: " $t$ he world view of the African and
Afro-American societies in question is such that the altered state of consciousness manifested in the act of spirit possessio is highly desirable and ardently sought."

${ }^{28}$ See Durkheim's (1995:347) analysis of sacrifice: "[s]acrifice is certainly a process of communion in part. But it is also, and no less fundamentally, a gift, an act of renunciation."

${ }^{29}$ Specifically, a verse and ese from the İretè Meji, here translated by the Awisho of Oshogbo, Yemí Elébuibon: "[Orunmila said, as from today on, no İfa priest should use human bloo to appease his inner head any longer" (Eleburuibon 2004:79). was on the verge of unknowingly purchasing his own son was on the verge of unknowingly purchasing his own son
for sacrifice; when he heard the boy recite verses that only his son could have known, he recalled a barren woman he had met in the bush. is in most cases eaten. Still, a typical initiation ritual necessitates the sacrifice of different animals, including rats, turtles, goats, et cetera (personal communication, May 2012), and these animals are killed in a ritual context expected to elicit the participation of a deity or spirit that responds to the blood of those animals. ${ }^{30}$ Particularly from a Christian perspective, blood sacrifice is not only unnecessary, but in many cases considered offensive. The emphasis in Ifa/Orisha on blood sacrifice is doubly alarming given the animistic premise of ascribing not only sentience but intelligence to animals and even plants. Many $O d u$ verses feature narratives involving non-human and non-Orisha actors, including the Òsé Òtúrá, a charming story about an earthworm who enters heaven to confront his father and earn the inheritance that his brothers (various species of snake) denied him: power (àse). This power is what enables the earthworm to burrow (Fama 1994:87-103). There are many $O d u$ verses that serve to explain features of the natural world, describe interrelations common to social life, and establish parameters of behavior in a world populated by spirits of all kinds.

The respondent identified as a practitioner of Peruvian shamanism also indicated that there is a tendency to associate African practitioners with the brujo of South America, who practice without a strict moral compass (personal communication, November 2012). Morally "right" or "wrong" are difficult terms to unravel in this context, but based on the answers of respondents familiar with indigenous shamanic traditions, the ethical framework of the system depends on the use of

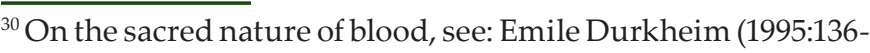
137): "[t]here is no religious ceremony in which blood does not have some role to play." power, itself dependent on the deity to which a practitioner directs his or her worship. ${ }^{31}$ Some are morally gray, unpredictable deities; others are dangerous and demand highly questionable practices from their worshipers; others are benevolent, "white" deities. Similarly, one may use his or her access to the spiritual world for good or for ill, to heal or to harm; and he or she will reap the consequences accordingly. One respondent, a Yoruba worshiper, said: “This man went to consult the priests, and they told him that he should not send Esu to kill someone. He did not listen. He went and consulted Esu, and Esu turned against him. He died" (personal communication, March 2013). It is clear that the Ifa Corpus is not morally neutral; many of the stories in the tradition encourage moral behavior. Still, the principal emphasis is not on morality as such, but on performing the prescribed $e b o$.

Participants in Ifa/Orisha engage a larger community of practitioners and worshippers that accept as true the fundamental premises of the religion, in whole or in part. The efficacy of babalawo and certain rites is assumed (Mauss 2001:114-120) and reinforced through periodic or cyclical engagement. ${ }^{32}$

$\overline{{ }^{11}}$ Durkheim (1995:215) writes: "[t]hus, both the moral power conferred by opinion and the moral power with which sacred beings are invested are fundamentally of the same
origin and composed of the same elements." For Durkheim the totemic principle at the base of religious activity is a social and, to a certain extent, a moral one. It is this principle that imbues subsequent ideations of gods and goddesses. However, it seems that this fundamental principle is more than capable of more complex diversification, embodying experiences that are degrading as well as uplifting, terrifying as well as inspiring, grotesque as well as sublime. If so, the moral element is removed from prominence and associthe mortal and divine worlds.

32 Prus (1997:46) writes "[Clyclical subcultures refer to those

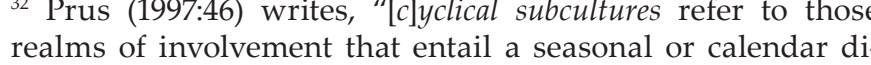
realms of involvement that entail a seasonal or calendar di-
mension...At more of a local community level, any variety of festivals and events represent annual or seasonal instances in which certain (subcultural) practices may be invoked." 
More importantly, however, involvement is maintained through narrative and storytelling, active on many levels in a variety of forms. Dynamic narratives that are taken from sacred space and integrated into profane life are essential for two reasons: first, they maintain both personal and collective connections to the sacred space of the rite or consultation (where/ when the narrative was created), and secondly, they strengthen symbolic or mythic associations to the belief system. When the outcome of an Ifa consultation comes to pass, in one form or another, participants are quick to point out that it was because the rite was effective in eliciting the involvement of certain entities.

Unfamiliarity with Ifa/Orisha may create a belief based on fear, superstition, and stereotype. For example, upon stating my desire to visit Oshogbo, one Nigerian respondent expressed genuine concern and apprehension, vehemently indicating that-although she was from Lagos-she would not go anywhere near the Osun Shrine. When I asked why, she maintained that witches were known to kidnap people and forcibly convert them. The victims would either remain among them indefinitely, or would leave entirely transformed by the experience, virtually unrecognizable to their families (personal communication, October 2011).

Sustained engagement with Ifa/Orisha may be due to experience (i.e., a "genuine" religious and/or mystical experience validating the premises of the tradition [Prus 1997:137]) or traditional upbringing (a form of cultural or collective experience). Nearly all of the Yoruba respondents indicated one or both of these influences. In many cases, the second exists as a cultural and ethnic gestalt; most Yoruba respondents claimed relatives who were practitioners and/or participants. Younger respondents of Yoruba origin (18-24) exhibited a greater diversity of responses with respect to participation and experience. Among those who claimed direct relatives who were worshipers, initiates, or practitioners, belief was a more pronounced element, often due to personal experience or exposure to a pervasive, social narrative of affirmation. Members of a congregation reinforce one another's belief and continued investment, not only as a means of maintaining the solidarity of communal identity, but also to perpetually rejuvenate the mythology. If Osun, Ogun, $\mathrm{Esu}$, and the other deities were not considered very much active and alive, the Ifa/Orisha tradition may have since become no more than an ethnographic curiosity.

Interestingly, one practitioner admitted that without collective belief many of the Orishas would fade away from the world. I asked him what happened to spirits when they faded away. He shrugged and answered: "They go into the earth to sleep" (personal communication, January 2012). Mauss (2001:154) writes: "[a] group's beliefs and faith are the result of everyone's needs and unanimous desires. Magical judgments are the subject of a social consensus, the translation of a social need under the pressure of which an entire series of collective psychological phenomena are let loose." The Orishas are certainly believed to respond to needs, embodying forces that tangibly affect the objects and circumstances of personal and public life. Individual lives are bound up in a multitude of engagements that may feature the Orishas, Odu, ase, or other elements of the religion as a common, binding narrative that may provide a sense of both personal and collective continuity. In the midst of radical change, it may be that Yoruba participants are reinforcing their collective identity through Ifa/Orisha in the same way that groups in South America and throughout the Diaspora use comparable spiritual traditions to construct and realize group identity.

Among both Christians and Muslims in Nigeria who strongly identified with their religion, skepticism or antagonism towards Ifa/Orisha often arose from doctrinal loyalty. They considered Yoruba spirituality a brand of idol worship. Importantly, unlike those who did attribute some sort of power to Ifa and the Orishas, respondents in this grouping indicated that the Orishas simply did not exist, and that those who worshipped them were performing meaningless gestures before empty objects. Respondents who expressed this position were either Western, or Christian Nigerians exposed to Western culture and education. ${ }^{33}$ Northern Nigerians expressed both of these positions far more commonly than they did any kind of belief. However, non-Yoruba, Hausa Muslims who believed in juju, charms, talismans, bush-spells, and the like were likely to attribute actual power to the Orishas of Yorubaland while claiming that those spirits "didn't belong to them" (personal communication, November 2011). Skepticism also appeared among certain younger

${ }^{33}$ Bear in mind that most education in southern and eastern Nigeria is "Western." Traditional educational models, based on apprenticeship, direct observation, and social narrative,
still exist: but formal education as such is typically British or American in format. Western educational models are mission-based and aggressively Christian, or they are products of an intellectual tradition that is expected to encourage development and modernization-often at the expense of valuing a rapidly diminishing cultural heritage. participants; one respondent indicated that he did not know enough to say whether the spirits did not exist, and did not want to offend them in the event that they did (personal communication, May 2012).

Many younger respondents who opposed traditional practices expressed a curiously high degree of nationalism. Rather than see traditional practices as a unique and irreplaceable cultural resource, they viewed them as hindrances to modernization and development. Respondents dismissed indigenous practices as primitive and obsolete, rooted in an ignorance of the natural world and the discoveries of science.

The Nigerian movie industry, known as Nollywood, produces many films that present indigenous African religions as malevolent, sinister, or as the antithesis of Christianity or Islam. Adelakun (2010) writes: "[l]overs of Nigerian films will be familiar with this trend: a man or woman who wants to harm his/her neighbor goes to Ifa priest to help. He/She is given a charm and the evil intention most likely succeeds...a Christian pastor or Islamic cleric is invited to pray for him/her...the power of light which Christianity/Islam represents is seen as having triumphed over darkness and evil which the African traditional religion is seen as representing." Yoruba filmmakers are responding with productions of their own. ${ }^{34}$ Unlike other, lesser-known indigenous African traditions, Ifa/Orisha is international. Many practitioners are taking advantage of this fact by

34 Prus (1997:74-75) writes: "[w]here outsiders define certain subcultures as undesirable, they may sponsor certain tices and participants associated with specific subcultures. Subcultural insiders wishing to promote their own pursuits may also sponsor media messages as tools." 
promoting Yoruba religion as a cultural resource. My own interest and involvement was interpreted in this light, and I was encouraged by several practitioners to represent their belief system accurately and honorably to the outside world. ${ }^{35}$

One thing that becomes clear when inquiring into the philosophy of indigenous practice is that faith is not defined in the same terms; that is, in the sense of holding something as true that cannot be proven. Rather, sufficient evidence is considered abundant. This is true for many shamanic and traditional practices; they are based on tangible results in the physical, phenomenal world. Practitioners are generally paid by their clients, and as such are part of the economic system of a given culture, offering a service in exchange for money or goods. Simply put, if they do not deliver, any trust in the efficacy of their work will be erased, and they will not be called upon to perform any of the services attributed to the traditional practitioner. In Ifa, for example, a diviner's predictions are expected to come true; moreover, if a threat is averted, it is also expected that the client should know and recognize that the "treatment" prescribed by the diviner successfully protected him/her. Chief Fama (1994:39) writes in her explanation of the İtàn attending the İrosùn Ogbè: “[i]n Yoruba culture, only versatile and proficient Babalawos are qualified to divine for kings. In the past, a Babalawo that divined for an Oba was required to live in the palace until his Ifa messages came to pass." 35 My methodology in gaining practitioners' trust is advocated
by Prus (1997:232): "[r]ather than becoming a convert...it may
be more accurate to envision an effective researcher as one
who takes on the situated role of an apprentice in the world
of the other...insiders who adopt roles of teachers, guides, or
research partners of sorts are particularly effective in commu-
nicating their experiences with the researcher."
Mauss (2001:115) writes: “there has always been a pressing urge to support magical beliefs by providing precise, dated, and localized proof," and: "along with this 'will to believe,' there is plenty of proof of actual belief" (2001:118). The practitioner is willing to believe in the efficacy of his own rites because, as Mauss (2001:118) argues, "[h]e is not a free agent. He is forced to play either a role demanded by tradition or one which lives up to his client's expectations." Obviously, among non-practitioners who discredit Ifa/Orisha, the rites belonging to the tradition are at best devoid of meaning, and at worst a perpetuation of an entrenched, ignorant form of primitive cult worship. Among practitioners, however, the efficacy of ritual practices is determined by a relatively liberal process of interpretation and association. While the Orishas themselves do not act outside of their jurisdictions or contrary to the entire (and often contradictory) range of their temperaments and habits, the symbolic and literal chain of events that links the ritual to its objective can assume a variety of forms. Similarly, when an objective is not attained, there are any number of explanations for the failure ${ }^{36}$; not the least of which is the absence of sufficient ase, typically attained and strengthened through sacrifice. If this happens, there is a bargaining, a give-and-take between the practitioner and his client (personal communication, January 2013) that may include adding to the originally prescribed sacrifice. If the second attempt proves fruitless, only then is the cred-

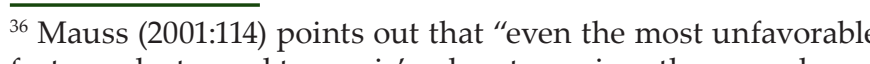
facts can be turned to magic's advantage, since they can always be held to be the work of counter-magic or to result from an error in the performance of a ritual..., the failure of a magical rite,
far from undermining the people's confidence in the sorcere merely endowed him with greater authority, since his offices were indispensible to counteract the terrible effect of the powers, which might return to harm the clumsy individual who had unleashed them without taking the proper precautions." ibility of the practitioner called into question-and quickly diffused by a willingness to believe that the spirits proved uncooperative on this occasion.

When asked to explain why he believed without doubt, a Yoruba non-practitioner familiar with Ifa maintained that anyone who doubted should

ask around. Everyone will tell you that it works. There was this man who stole a lot of money from a worshiper. The worshiper goes to consult Ifa, and they now tell him that he should make a sacrifice. If he makes this sacrifice, the man will die. Within seven days, he died. (personal communication, November 2012)

I asked the respondent whether this was considered "black magic," and he indicated that it was dangerous to send a spirit after someone, but that the men and women who did such things were dangerous people.

I should point out that there is no "secular Orisha-ism" in Nigeria, ${ }^{37}$ no move towards separating the cosmological and supernatural elements from its moral, social, or ethical dimensions. In fact, this would likely be impossible. Many outsiders, particularly respondents from the United States, perceive African spiritual traditions as composed primarily of supernatural and ritualistic elements, and containing very little, if any, intellectual or moral components. This is not an uncommon perspective among those with a low degree of exposure to Yoruba concepts. The picture changes considerably

${ }^{37}$ In the way, for example, that there is a "secular Buddhism," nowadays associated with the writings of Stephen Batchelor,
who wrote the popular Buddhism Without Beliefs. among those with higher degrees of exposure, and is entirely different among those who are familiar with the traditions.

Witchcraft-prominent examples of which are constantly circulated across a variety of mediums ${ }^{38}$-is aligned with what a Westerner would call "black magic." Many Nigerians believe witches to belong to "secret societies," or cabals of practitioners who are responsible for any number of crimes and catastrophes across the country. Active in both rural and urban areas, secret societies are believed to abduct and initiate children, commanding them to steal from or murder their families. ${ }^{39}$ Adult members are believed to possess a range of terrible powers, most of them malignant in nature. Opposed to secret societies and their nefarious members are priests, pastors, preachers, traditional healers and medicine-men. More than a few Nigerians, even in the north, carry various charms that ostensibly protect them from the machinations of witches. These charms and amulets are

${ }^{38}$ Including church newsletters. In one example, on the "testament" page of a particular newsletter, a "witness" claime to have been abducted and forcibly initiated into a snake cult (a popular theme in Nigeria) where she was made to kill hundreds of innocent people in savage rituals. She was allegedly responsible for conducting the souls of her victims to the leader of this "secret society." This went on for years before she was found and redeemed by missionaries from this particular ${ }^{39} \mathrm{I}$ ${ }^{39} \mathrm{I}$ became privy to an alleged instance of child-related witch-
craft in 2013. The story began when I was informed that the craft in 2013. The story began when I was informed that the
young daughter of a friend's brother had been accused of trying to murder her grandmother, with whom she was living a ing to murder her grandmother, with whom shers were brought in, and they declared that the girl was possessed. They were unable, however, to exorcise the influence. About four months later, after another thwarted attempt to kill her grandmother, the child informed her family that members of a secret society had contacted her
to tell her that they would claim her blood as punishment for to tell her that they would claim her blood as punishment for afterward, the young girl died in the hospital. Everyone with whom I spoke concerning this affair expressed no doubt what soever that a secret society was to blame for the girl's illness and death (personal communication, April 2013). 
provided for a fee, and are composed of various local herbs bound in leather. The more powerful (and more expensive) charms are bound in pieces of burial shroud taken from an exhumed corpse (personal communication, March 2013).

Interestingly, Ifa practitioners themselves acknowledge the existence of secret societies that work with evil, "black," or "red" deities. A babalawo indicated that "The red is always looking for blood. Whenever something terrible happens and many people die - that is the red. Those who serve the red are always looking to kill, and take the blood" (personal communication, December 2011). The priest went so far as to name a number of recent accidents and insist that they were the work of practitioners who were using those accidents as a means of mass ritual sacrifice. However, practitioners of "bad magic" are punished if caught, and typically executed (personal communication, December 2011). Individuals unfamiliar with Ifa may be unaware that practitioners worship opposing deities and vie with one another for influence and spiritual territory. A Yoruba worshiper informed me that a group of practitioners from a neighboring town frequently assaulted IleIfe using bad magic, and that the babalawo and other practitioners of Ifa/Orisha had to defend against them (personal communication, May 2012). Foreigners who are unfamiliar with the traditional religious culture of Yorubaland (and Africa in general) may not realize that it is an often violent spiritual landscape. However, Nigerian respondents indicated that this is common knowledge; good and evil practitioners have always warred with one another, and both Christians and Muslims freely superimpose angelic and demonic connotations on extant narratives of earlier, precolonial traditions. Still, inasmuch as both Christianity and Islam are exclusive faiths, there is a diminishing space in Nigeria (particularly urban Nigeria outside of the Yoruba nation) for traditional religious specialists. ${ }^{40}$

Since the revivalist predilections of contemporary spirituality, the traditions of the developing world have attracted the attention of those interested in reclaiming, appropriating, and translating the wisdom of cultures that have not entirely succumbed to the homogenizing influence of modernization and globalization. Ifa is no longer another backward religion indistinguishable from similar religions throughout South America, Oceania, and Africa. It has become an untapped treasure-trove of active forces that address very earthly and material needs in ways the monolithic religions do not. For practitioners, the ability to integrate diverse expressions across varied mediums of exchange allows for an interface unavailable to many indigenous systems throughout the Continent. However, interactions between the storytellers of Ifa/Orisha and the extended worlds of both practitioners and non-practitioners are opening spaces of unpredictability, conflict, and negotiation. ${ }^{41}$

Whether the commoditization of spirituality is positive or negative is not a question addressed by this article (see: Carrette and King [2005] for a detailed analysis of this phenomenon). Suffice it to say that

${ }^{40}$ Again, this is not true in the Diaspora where the number of initiates and practitioners is growing.

${ }^{41}$ Prus (1997:44) writes: "[iln all instances, however, it is the " Prus (1997:44) writes: "Ii]n all instances, however, it is the dation of the larger (translocal, regional, transnational) subculture in question." the Yoruba traditions have not escaped the attention of a peculiar sort of consumer: the spiritual tourist. Just like any other resource on the market, value is proportionate to demand. Identifying the nature of the demand is necessary to understanding exactly how Ifa/Orisha is valued or objectified as a commodity. The demand itself tells us about the consumer, and a distinguishing characteristic of the spiritual tourist is a willingness to believe in at least one aspect of the premises that support a given tradition. Unfortunately, there is a tendency to be reductionist here, and many spiritual tourists myopically impose Western dichotomies on indigenous systems, that is, traditional versus globalized, genuine versus mediated, original versus derivative. Seen from behind this tinted lens, Yoruba spirituality becomes another romanticized religion, closer to an idealized source. ${ }^{42}$

As part of the Diaspora, Yoruba spirituality is easily as global as any of the major religions. As a highly syncretic religion, particularly in the Americas, one finds the Orishas commonly mediated through analogous Catholic saints. The Yoruba pantheon is also a composite of deities brought together from a variety of tribal groups in the precolonial history of West Africa. J.D.Y. Peel (1997:275) writes on Ogun: "[t]he prominence of any one of Ogun's potential meanings or functions in a particular place depends partly on local circumstances...it is also af-

$\overline{42}$ Carrette and King (2005:78) are highly critical of spiritual tourism, and with good reason: "[w]hile 'New Age' followers dance the gospel of self-expression, they service the financial While they selectively ravage the feel-good fabric of ancient cultural and religious traditions, their disciplines and practices can easily isolate them from the resources of social justice and community to be found within those same traditions." fected by what other deities are present in any local complex of cults...These complexes are the practical, concrete reality of Yoruba religion." However, Ile-Ife is known as the "Source," and it is more than likely that there are elements of the Corpus that have remained relatively unchanged since the Bantu Expansion. The perception of practitioners is that Ifal Orisha has survived, and the further one moves from urban centers built on the history of colonialism, the greater the likelihood that threads of older practices continue to find expression "in the bush."

Africa, and Nigeria in particular, is developing quickly. Perceptions of traditional religions are changing; their continued survival is not due solely to their ability to adapt and change, but also to their ability to resist change. Yoruba spirituality has been able to walk this tightrope in Nigeria, but-as is historically the case-traditions need defenders and advocates who are capable of representing and resolving this tension between resistance and adaptation. These representatives participate in the construction of multi-vocal narratives that allow the voice of the religion to be heard in different contexts (e.g., local, national, global) and translate that voice into mediums foreign to it. For example, traditional practitioners likely did not need to explain the mythology or reasoning ${ }^{43}$ underlying their work anymore than a citizen of classical Greece needed to be told who the Olympians were. Now, invited into a marketplace that extends across cultures, the Orishas are obligated to explain themselves in ways

${ }^{43}$ According to Mauss (2001:119), "[m]agic is believed and not perceived. It is a condition of the collective soul, a condition which is confirmed and verified by its results. Yet it remains mysterious even for the magician." 
formerly unnecessary. Karen McCarthy Brown (1997) describes a worshiper "mounted" by Ogun who channeled the deity in a way uncommon to normal manifestations of the Orisha:

[t]he tearful despair of these New York Ogou is a facet of the spirit's character that is difficult to imagine being acted out in Haiti. Perhaps a new dimension of the Haitian Ogou is emerging in the North American setting...However, the Haitian Ogou has not taken up the challenge of interpreting modern technology, as he has in Nigeria. (p. 83-84)

Modern practitioners must contend with an "unwillingness to believe" that results from an opening or fragmentation of unified, collective investment and participation in sustained practice or storytelling. This has most certainly taken place in Nigeria. How practitioners respond to this challenge varies, but it is enough for the moment that multiple trajectories of engagement exist: from the representation of Orishas and their devotees in popular media and entertainment, to scholarship conducted by outsiders and insiders, to translations of the Corpus, to the maintenance of direct lines of transmission and carefully moderated instruction and apprenticeship.

In effect, the point of interaction between practitioner and non-practitioner is not only ideological and social but direct. The Yoruba spiritual tradition is primarily concerned with the world, and is therefore active in the world, rather than eschewing worldly pleasures and acquisitions. Belief is reinforced by two key elements: a causal and direct relationship between ritual actions and their intended effects, ${ }^{44}$ and the fact that the symbolic narrative of the tradition is continuously adapted and rewritten to suit changing social contexts. Given these elements, it is no surprise that Yoruba spirituality survives and continues to proliferate across many of the same channels that once facilitated the Transatlantic Slave Trade. In fact, West African spirituality-not limited to the Ifa/Orisha traditions of Nigeria-has not only survived but has adapted itself to a world dominated by the neoliberal marketplace.

\section{Philosophy}

Ifa/Orisha is a polytheistic system. The bickering, anthropomorphized deities of classical mythology in the Western world are not dissimilar to the Yoruba gods, who likewise quarrel, engage in common human behavior, and experience difficulty. The Orishas are also assigned powers and jurisdictions; they possess defining characteristics and are easily syncretized with comparable deities across ethnic and cultural groups. Also similar to the gods of old, the Orishas have very specific preferences and taboos that must be observed by worshipers and initiates. The deities are actors in an extensive corpus of narratives that serve a number of functions: they answer questions about the appearance and machinery of the natural world; they establish the boundaries of ethical behavior; they stabilize and validate the social and political community.

${ }^{44}$ This involves the law of sympathy or contiguity, described at length by Mauss in A General Theory of Magic, originally published in 1902. In essence, the direct correlations necessary to magical or ritual efficacy are the result of collective belief in 2001:86). While this range is similarly limited in Ifa/Orisha, the narrative possibilities available with which an individual o group may mythologize, interpret, or assign a causal link between ritual and effect are far more extensive.
At this juncture, it may be helpful to point out that Ifal Orisha is both a magical and religious system. The rites and rituals of sacrifice, initiation, divination, et cetera have a magical character dependent on the actions of an authorized practitioner. The system itself operates according to the laws associated with magical operations, including contiguity, contagion, and sympathy. However, according to Mauss (2001:30), “[a] magical rite is any rite which does not play a part in organized cults -it is private, secret, mysterious and approaches the limit of a prohibited rite." Elements of public/social and personal/private worship and ritual exist in Ifa/Orisha. The babalawo is the priest, and the wilderness may well serve as a temple of collective worship. There is both mystery and openness in the tradition that bridges the untamed forest and the village, the seemingly changeless rural settlements with urban centers that race towards modern development. In many ways, it is the magical character of Yoruba religion that works as the primary locus of unity, coherence, and narrative compatibility. This is uncommon, inasmuch as knowledge transmission and instruction are generally highly localized and depend on the unbroken continuity of a specific stock of rites, rituals, formulae, et cetera. The open dissemination of magical knowledge is counterproductive. However, what is remarkable here is that the religious elements of Ifa/Orisha do not exist independently of the mythological and magical elements, but work to bolster them by empowering local practitioners. By accessing the religious elements-social, moral, philosophical, and mythological (inasmuch as mythologies cross religious-magical boundaries [Mauss 2001:105]) - practitioners are able to reinforce the ongoing mythos of collective participation and strengthen the relevance of symbolic correlations between disparate fields of engagement.
The mythology changes and adapts depending on the practitioner and the lineage. Bascom (1980:32) writes: [t]he verses confirm, supplement, and at times contradict what is known about Yoruba religion, revealing how beliefs vary, with cult members often assigning greater importance to their own deity than is generally recognized." Practitioners may be any of the following:

3. Priests, priestesses, babalawo, et cetera, who conduct ceremony and perform sacrifices, initiations, divinations, and consultations, and administer traditional medicines. Included in this set are those who engage in rituals of "mounting" or spirit possession. ${ }^{45}$

4. Initiates who are not qualified to perform advanced ceremonies, and who are undergoing apprenticeships. This set is complicated by a number of initiates who do not receive instruction in the traditional way, that is, living with the priest and learning through direct observation. Some may travel periodically to receive instruction or participate in ceremony, supplementing their instruction by accessing modern sources of information, including transcriptions of the Corpus. ${ }^{46}$

${ }_{45}$ Outsiders generally identify this ritual with Haitian Vodun, but it is an integral part of West African spirituality. Margare (gìn) the devotee (elégrinz, literally, 'one who is mounted') and, for a time, that devotee becomes the god. Temporarily, then, the animating spirit of the deity (èmi orisä) displaces that of the individual being mounted."

${ }^{46}$ Some "practitioners" are taking advantage of unorthodox methods of instruction to swindle those interested in becoming initiates. One respondent informed me that this practice is common, particularly towards foreigners: "If you don't know someone whe knows a priest and can vouch for you, if you try and find someimportant that you know someone who can speak for you to the important that you know someone who can speak for you to the
priests. But, this is not always a bad thing. Plenty of foreigners priests. But, this is not always a bad thing. Plenty of foreigners
come to learn Ifa who don't know what they are doing, and that can be dangerous" (personal communication, April 2013). 
5. Worshipers. Many worshipers keep shrines to the Orishas in their homes, participate in public ceremonies, and engage in a variety of other activities that express belief in the deitiesdrumming, reenactments, swordplay, et cetera. Thousands of worshipers attend ceremonies dedicated to Osun, Shango, Ogun, and Obatala.

All of these are considered to be familiar with the tradition; based on interviews with practitioners from each of these sets, I will briefly discuss a few major premises that address the philosophy of the religion.

The first regards the relationship between humankind and the divine. Unlike the three primary monotheistic religions of the world, human beings cannot address the Creator directly. Oludumare can be accessed only through intermediaries, each with its own jurisdiction, power, and relationship to the others. These intermediaries are the Irunmolé, the Odu, the Orishas, ancestors, and innumerable lesser spirits. While many of these deities are considered "good," most of them nevertheless occupy a range of moral positions. They can be aligned in accordance with three primary forces: white, black, and red. An Ifa priest described the deities associated with these forces in the following way: "...white is cool-headed, good, helpful, creative, and life-giving. Red is hot-headed, violent, powerful, virile, and difficult to appease. Black is unpredictable, dangerous, and destructive" (personal communication, May 2012). There are troublesome spirits as well, akin to the demons of the Judeo-Christian-Muslim traditions, but they are not linked to a single orchestrating source of evil.
It is often problematic to outsiders from the West that Ifa/Orisha spirituality does not abstract and personify Good and Evil in the same way that the monotheistic religions do. In fact, West African spirituality is arguably more complex in its polytheism than the duality that frames many expressions of monotheistic theology. The neo-Platonism and Manichean philosophy that influences Christianity is absent here. This does not mean that the practice is amoral, but rather that the individual is responsible for his or her own harmony and balance.

In Ifa, balance is negotiated between the human being and his or her ori (inner head or ancestral spirit). Similar to Western concepts of the Spirit, the ori is virtually autonomous in its own right, appointed to an individual as a guide. ${ }^{47}$ An individual can have a "good head" or a "bad head" (Bascom 1980:34), implying good or bad fortune. Respondent practitioners indicated that the ori is often called one's "destiny." Durkheim (1995:283) addresses this concept in his analysis of the individual totem or ancestor spirit: "[w]e cannot become fully merged with it because we ascribe to it a stature and a respect that lift it above us and our empirical individuality." This holds true for the ori. An individual that neglects to satisfy his or her "inner head" will be chastised and made to endure all manner of misfortune; not only on account of his or her ori, but because the withdrawal of the ori's protection attracts the influence of

${ }^{47}$ Bascom (1980:34) writes: "[i]nformants stress the importance of the ancestral guardian soul, some even calling it a deity."
In his translation of an Eji Ogbe verse, Orunmila is told to accord proper respect to the source of his good fortune: "Ithey cord proper respect to the source of his good fortune: "I $\mathrm{t}$ hey you so.'... Shout, 'Head, oh! Head is what makes a boy a man. Yes'”' (Bascom 1980:129). negative forces (personal communication, January 2012). For Durkheim, the ancestor spirit was a personification of a doubled self (1995:283), a means of resolving the duality that characterized the social, communal involvement of an individual as distinct from the day-to-day responsibilities more properly belonging to the profane realm (1995:390). This suggests that the displeasure of this ancestor spirit is a projection of the communal self's $\mathrm{s}^{48}$ shame, based on the awareness that he or she may have strayed beyond the accepted norms or conventions of his or her social obligations. This may not be entirely untrue as the ori's sanctions are responses to moral or social transgressions (i.e., not paying for a sacrifice, failing to respect a mutual contract, etc.). However, practitioners also indicated that taboos may be entirely personal in nature, having nothing to do with social conventions or regulations, and that these taboos are imposed by an individual ori in accordance with a highly intimate relationship. These taboos are given to initiates-or rather, revealed to initiates-by a babalawo in ceremony. They remain thereafter a secret matter, to be steadfastly observed by the individual. Indeed, a practitioner indicated that to openly speak of one's personal taboos is dangerous, insofar as it more easily leads to his or her breaking them (personal communication, May 2012).

The spirit of an individual, associated with his or her energy or power (ase), is strengthened in two ways: when one is in alignment with his or her inner head/destiny, and through worship and sacrifice. Ase is both personal and impersonal; it can be

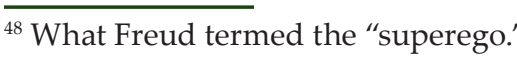

stolen, exchanged, gifted, and drained. It can also confer an ability or power on an individual, and it is considered the source of talents and/or unique characteristics. John Pemberton (1997:124) writes" ${ }^{49}$ “ “[à]se does not entail any particular signification, and yet it invests all things, exists everywhere, and, as the warrant for all creative activity, opposes chaos and the loss of meaning in human experience. Nevertheless, àse may be used for destructive ends."

Ase is comparable to the mana treated by Durkheim (1995:214): "the environment in which we live seems populated with forces at once demanding and helpful, majestic and kind, and with which we are in touch. Because we feel the weight of them, we have no choice but to locate them outside ourselves," and, "[r]eligious forces are in fact only transfigured collective forces, that is, moral forces; they are made of ideas and feelings that the spectacle of society awakens in us...they are superadded" (1995:327). Mauss categorizes mana as a quality, thing, and force (2001:135), describing it "like something superimposed on another. This extraneous substance is invisible, marvelous, spiritual-in fact, it is the spirit which contains all efficacy and life" (2001:137). This idea is central to both magic and religion, particularly in their earliest forms; although, even in Protestant Christianity, the Holy Spirit is considered to work similarly (personal communication, September 2012). Ase is neutral, pervasive, and requisite for virtually any endeavor; it can be channeled into manual labor, artistry, and other human enterprises; in its unadulterated form, it is the fuel of ritual activity. An insufficient reserve of ase diminishes ${ }_{49}$ Taken from Pemberton's analysis of a traditional Ogun
Festival. 
the efficacy of a rite. Ase is both individual and social, although it clearly exists at the intersection of individual and collective life. It can be cultivated individually and used to effect change in the social world. It is both necessary for, and strengthens sacrifice; and the most powerful sacrifices are performed collectively. Ase is weakened through disharmony with the ori, a tension that is incurred through-as Prus (1997:140) might suggest-a mismanagement of one life-world or another. ${ }^{50}$ However, participant respondents emphasized the highly personal quality of the ase alongside its ubiquity; this personal quality was not unconditional, however, and one could lose his or her power, as well as gain, regain, and exercise it. It was in this way tied to personal actions, albeit relative to the community for the most part, though also dependent on the maintenance of entirely personal taboos and obligations.

Ritual taboos are determined by the specific Orisha or lineage and typically involve restrictions that deal with diet, offerings, dress, and habits of worship. Consider this verse from the Owonrin:

[t]o be told and to like it,/ To be given advice and to accept it/ Cast for Disobedience/ When he was going to take land for a farm on the road to Igbale./ The hoe that cleared the land,/ It chopped the head of Egungun./ Egungun opened his mouth and was singing,/ "You knew the taboo;/ Why did you do it?" (Bascom 1980:709)

${ }^{50}$ In other words, inasmuch as ase is also destiny, nearly every individual decision can be measured in terms of whether or not it accords with, deviates from, or directly opposes the fortunes allotted to one's course in life. This may sound rather
like predestination, and that comparison would not be entirely unfair: many worshipers experience a good deal of trepidation when consulting a babalawwo regarding the orientation of their ori, for fear they will be told their fortunes are ill-favored or insignificant (personal communication, May 2012).
The emphasis in these few lines is mirrored in many of the $O d u$ verses and is centered on two elements: taboos and sacrifices. Taboos maintain an intricate network of relationships between the mortal and immortal communities and stress the importance of both discipline and obedience. Sacrifices serve in a similar capacity, and additionally facilitate exchanges between the two worlds. The blood of a particular animal sacred to an Orisha (e.g., as dogs for Ogun or white hens for Osun) serves as a conduit for the conveyance of a prayer or message. A response is expected from the Orisha in question. If there is no response, the ritual may be repeated or additional methods used to elicit a tangible reaction. If silence persists, the endeavor is abandoned and another means of address sought (personal communication, May 2012).

If one looks at religious concepts evolutionarily, according to the typology developed by Weber (1946; 1963) and Marriott (1955), the Orishas are "limited by their specificity. They fail to link diverse peoples together, because they are concrete, because they are parochial and therefore tied to concrete places and groups, and because they represent only part of the cosmos" (Barnes 1997:22). Barnes (1997:19) goes on to point out that evolutionary typologies of religion are entirely insufficient for an appropriate analysis of Ifa/Orisha deities: "[t]he ability to appeal to a universal...culturally plural audience rests on what a deity means: what, in fact, a deity signifies, symbolizes, suggests, and intends and the ways these elements are expressed." Barnes' (1997:19) analysis is focused on Ogun, who "is a profoundly satisfying symbolic expression of a human dilemma: how to balance the need for constraint against the need for freedom."
Ogun is transcultural, Barnes (1997:20) suggests, in part because he is a "root metaphor," in this case for an experience that is universal to humankind: the creator/destroyer dichotomy, the smith who makes the tools that cultivate and the tools that kill. Obatala, Orunmila, Osun, Esu, Shango-these are also root metaphors for a vast range of individual and collective experiences.

Durkheim (1995) takes another approach, which merits consideration:

[t]he tribal high god is actually none other than an ancestral spirit that eventually won a prominent place. The ancestral spirits are none other than entities forged in the image of the individual souls, the origin of which they are meant to account for. The souls, in turn, are none other than the form taken by the impersonal forces that we found at the basis of totemism. (p. 299)

These anthropomorphized impersonal forces are similar to Barnes's root metaphors, but, in the life-worlds of practitioners and participants alike, the Orishas are living entities that are at times dangerous, unpredictable, independent, and contradictory. Prus (1997:137) writes: "the primary concern is not over whether something is 'truly religious' or not, but rather with the ways in which people develop life-worlds around 'phenomena' that they deem worthy of devotion in some more enduring respect." Practitioners and participants both create multiple life-worlds around their relationships to various Orishas; respondents would likely insist that Osun, Esu, and the rest have multiple life-worlds of their own.
Questions of origin-of where the spirits "come from"-are relevant in terms of the mythology, but the spirits themselves are believed to maintain their own narrative continuums both in the present and backwards in time. So, it is equally likely that a practitioner would argue that people simply were not able to recognize the Orishas until by necessity or innovation their efforts brought them within the jurisdiction of one spirit or another. Sandra T. Barnes and Paula Girshick Ben-Amos (1997:39) write: "[b]asically, the Ogun concept encapsulated the progression from hunting to agriculture and the mastery of metallurgy, to urbanization and, ultimately, in these peoples' own view, to the development of empire. In one symbolic complex there existed a recapitulation of each kingdom's stages of growth." One respondent indicated that "...the Orishas are always teaching us. They do not teach us until we are ready to learn.” I asked him, “What happens when you've learned all there is to learn?" The man laughed and said: "That is something only an oyinbo would say. There is always something to learn" (personal communication, January 2012). In other words, ase did not so much develop into the Orishas; rather, when human communities or singularly heroic individuals had attained a mastery of ase that enabled them to invoke the deities, the Orishas themselves instructed them in the rites that would thereafter order the relationship between the two worlds. The Orishas did not replace the concept of ase; it became the dominant currency in the dialogue between the mortal and spiritual worlds, no less important in today's practices than the sacrificial offerings themselves.

Ifa/Orisha narratives are neither linear nor circular in time, but layered and beaded together by 
a consistent web of associations, symbols, and collective representations. The Orishas may be archetypal in a sense, but they are neither irreducible nor amorphously universal. Nor are they merely social forces wrapped in layers of mythology-not to the practitioner. They are actors in a larger drama that fuses societies (even across countries and oceans), acknowledges both individual and social roles, and preserves continuity through adaptation.

Respondents who identified themselves as strongly Christian or Muslim commonly viewed Ifa as a form of idolatry, which is only technically correct inasmuch as practitioners do make offerings "to" graven images. I use the quotation marks because I clarified this point with a priest of Osun:

You do not make a sacrifice to the stones. The stones are not Ogun, they are not Esu. You do not worship the stones. It is this way: when you call the spirit, the spirit comes to the stones; there is a quality in the stones that can hold the spirit. You make a place for the spirit. You welcome the spirit, and when it is there, you can communicate with it. (personal communication, January 2013)

This is a crucial distinction, but it is sadly the case that Christians and Muslims opposed to traditional religious practices do not appreciate the difference.

Apologists of Yoruba spirituality have attempted to stress the importance of Oludumare to the Orisha pantheon. This, as Cox (2001) notes, is likely a direct result of the interaction between Ifa/Orisha and Islam and Christianity. Cox (2001) cites Andrew Walls (1996): [f]or Walls, the fact that African religions almost everywhere have expanded their concept of God to include the Christian and Islamic emphases on an all-powerful Supreme Being makes the question of whether indigenous religions in precolonial times actually conceived of such a God largely irrelevant for discussions of contemporary African beliefs. (p. 337)

Peter McKenzie-whom Cox criticized earlier for imposing an inherently Christian typology on Yoruba beliefs-writes on Ulli Bier's analysis of Susanne Wenger's ${ }^{51}$ influence and attempt to create a "universalist òrisà doctrine": "[h]er cosmology appears to be a kind of pantheism or panentheism, with Olòdùmarè as the total of the All including the òrisà, and with each òrìsà a personalization of the universe, a...condensation of the forces of the universe at a certain place, seen from a certain angle" (1976:196). There is a good reason to be highly critical of imposing a theist interpretation on Yoruba spirituality. Patrick J. Ryan (1980:162) writes that “[n]ot only outside observers but also certain African Christian insiders have perpetuated a tendency, perhaps unconscious, to describe African conceptions of the transcendent in Semitic or Indo-Eu-

${ }^{51}$ Susanne Wenger, as McKenzie (1976:195) writes, was a "confor the òrisì to settle in after a long period of uprootedness. Susanne, an Ogbóni elder and a priestess of Obàtálá, has also done much for the official cult of Osogbo, Òsun. She has given support to the òrisà not only by encouraging astonishing work of art but also by formulating a kind of universalist orisì doctrine." While many respondents evinced a respect of Wenge and her work, there were several who considered her influence detrimental to the indigenous preservation, expression, an interpretation of Yoruba religion. An answer to this concern,
however, was voiced by a Yoruba respondent who said: "We can criticize her if we were doing something to preserve our own cultural heritage. She, a foreign woman, did more to preserve our traditions than we do-and now we are letting it $g$ to waste again" (personal communication, May 2012). ropean theological categories that are still basically foreign."

Ryan (1980:166) goes on to point out that "[o]ver all these orisa, Oludumare (Olorun) reigns supreme, the ancestor of no patrilineage, adopted as the direct recipient of no individual's sacrificial worship." The question of a Supreme Deity may be of concern to non-practitioners seeking to create open lines of communication between the monotheistic religions and Yoruba spirituality. It certainly was for missionaries who may have hoped to stage a recurrent drama: the ascendance of a single, omnipotent, and all-encompassing God at the expense of a lesser pantheon of spirits ${ }^{52}$ that would either be destroyed (played out through a loss of followers) or otherwise subordinated (as evidenced by one respondent's comparison of the orisha to archangels). However, while Christianity and Islam in Yorubaland are weathering away at traditional practices, the ability of worshipers and practitioners to adopt an inclusive position should not be underestimated.

A respondent addressed this issue in the following way: "Nowadays, people will pray to God or Jesus or Allah when it comes to things they cannot control. They still pray to the Orishas when it comes to things they believe they can-their problems, their hopes, their work; these things are still entrusted to

52 Durkheim (1995:288) expresses a similar concept: "[s]everal [Australian] tribes have achieved the conception of a god
who, if not the only one, is at least the supreme one, and one who, if not the only one, is at least the supreme one, and one
to whom a preeminent position among all other religious entito whom a preeminent position among all other religious enti-
ties is ascribed." What does it say about Ifa/Orisha that such an ties is ascribed." What does it say about Ifa/Orisha that such an
entity exists but cannot be invoked or otherwise addressed by portation, voiceless beyond the missionaries who insisted on his inclusion. Or, it may suggest a more Gnostic interpretation: that humankind had, at some point, lost the ability to communicate with him. the Orishas" (personal communication, May 2012). Worshipers who adopt two religions see no conflict of interest in following both. ${ }^{53}$ The Orishas are not competing with God in any way; on the contrary, it is understood that they are closer to humankind and as such can act on behalf of God in matters that fall under their jurisdiction. The Orishas are not generally reduced to "manifestations" of God save by outsiders to the practice who are actively seeking to resolve a conflict that does not exist for many practitioners. Still, one initiate referred to this interpretation, saying:

If that is how they want to see the Orisha, if that helps them understand the Orisha, then it is good. Only let them not be confused; each of the Orishas is different. Some of them are enemies and some of them are husband and wife. They are all worshipped differently. (personal communication, January 2013)

The primary concern of the spiritual tourist-as with many tourists in general-is with authenticity. This is set against a contrary position of in-authenticity, a concept often expressed in terms of a reaction against the prevalence of aggressive missionary or conversion-based religions in developing countries. This perspective is directly related to the perceived philosophy of traditional religions as holistic,

5 Prus (1997:46) writes: "interfused subcultures [refer] to circumstances in which people find themselves more or less simultaneously involved in or actively engaged in managing two or more situationally coexistent subcultures...What is most consequential about interfused subcultures are the multiplicity of
'central' activities and the problematic and shifting nature of 'central' activities and the problematic and shifting nature of
people's opportunities, involvements, and emphases within more or less concurrent timeframes.", One may apply this concept to individuals who engage two disparate religious matrices without necessarily partitioning loyalty. This is a complex symbolic and theological juxtaposition with a range of possible individual expressions. 
less doctrinal, more flexible, and more open to accepting significant differences in personal experiences of the supernatural or divine. In other words, an individual who undergoes a spiritual experience under the purview of a traditional ceremony may express that experience through multiple, even contradictory, narratives. For example, Barnes (1997: 17) writes of how devotees narrate their interactions with Ogun as both creator and destroyer: "[r]ather than resolution, an unending tension is maintained between the two sides of either equation...In African cosmologies where Ogun is a central figure, destruction and creation are two aspects of a unity that cannot be broken into opposing parts." This is also true for Osun who is commonly compared to Venus-even visually and symbolically-but whose aspects range from terrifying to seductive, matronly to virginal.

Raising this point with a Nigerian Catholic who identified as a worshiper, the respondent indicated that

Catholics are polytheistic in their own way, dividing God into three parts that can be considered separately but never separated. The Orishas are the same. They are all aspects of Oludumare, and they cannot be separated from him. It's just that, unlike the Trinity, the Orishas fight with one another, contradict one another, and interact with one another in very human ways. (personal communication, November 2011)

Granted, to many Catholics outside of Latin America and West Africa, this would be more than a minor point and an unjust and potentially blasphemous comparison. However, from the point of view of a practitioner, there is often a sense that mono- theism and polytheism are not mutually exclusive typologies. Barnes (1997: 12) writes: “[t]here are even triple blendings of Christianity, Islam, and indigenous systems. To classify them would be to misrepresent the nature of the phenomena or the abilities of adherents to layer ideas on one another, make analogies, or otherwise subtract and add in a variety of ways."

Priests of Ifa/Orisha, in contrast, seem unconcerned with typology altogether, although they will sometimes attempt to draw comparisons to Christianity in an effort to explain certain elements of the system. For example, a babalawo respondent indicated that Esu is syncretized with the Devil (personal communication, January 2013), a comparison that is highly problematic and misleading. Esu does inflict suffering, and he does often play tricks on human beings that may or may not be intended to impart a moral lesson; but this Orisha is rather similar to the archetypal Trickster figure. Some expressions of this archetype are primarily benevolent, if challenging, while others are as capable of outright malevolence as they are of kindness. Esu is like this. When queried as to the reasoning behind the syncretism with the Devil, this respondent added that

Esu is difficult to work with. Another priest kept Esu in his house, when you are supposed to keep him outside. He started having all kinds of trouble in his life; Esu was disturbing him seriously. He now had to buy another house, and keep Esu outside. Since then, he has no more trouble. That is why we say, Esu is like the Devil; he doesn't care. If you make a mistake with him, there is nothing you can do. (personal communication, January 2013)
There is another premise that merits attention in terms of how Ifa/Orisha is practiced and understood: the emphasis on worldly gains. Barnes (1997) puts it this way:

[a]frican religions tend to dwell on predicting, explaining, and controlling day-to-day circumstances such as illness, poverty, infertility, or bad luck...Stress on pragmatism is a part of non-Western traditions to a greater degree than in Western religious traditions, which put strong emphasis on transcendental functions, such as preparing for the hereafter or helping devotees gain faith or inner "grace." (p. 22)

This is a complex point to unravel. Panem nostrum quotidianum da nobis hodie; in theory, worldly concerns may be second to otherworldly ones, but they are certainly not absent from the prayers of those who adhere to Western religious traditions. Second$l y$, the emphasis of Ifa/Orisha ritual on the attainment of worldly successes is based on a premise of the utmost importance regarding the relationship between the earthly and spiritual; namely, that the earthly world is a reflection of, and directly connected to, the spiritual world. ${ }^{54}$

Typically, practitioners and participants in magical and religious traditions consider the world of the spirits and the world of men two separate worlds.

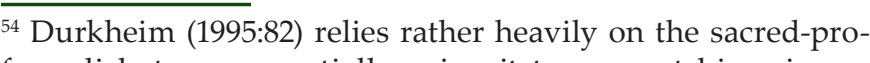
fane dichotomy, essentially using it to support his primary hypothesis regarding the collective and social origin of elementary religious ideation. However, one cannot effectively analyze the sacred designation applied to persons, objects, and
rites without understanding how participants construct both ites without understanding how participants construct both
worlds. Mythology is a primary tool in this respect, and is as invaluable in examining the "belief-worlds" of a community as dreams are to examining the interior, psychological world of an individual.
Obviously, the idea of Heaven, paradise, et cetera is related to this. However, Ifa/Orisha is somewhat different: this world, our world, is as much an arena of spiritual activity as is any other (personal communication, June 2012). Consequently, the boundaries between sacred and profane are perhaps more blurred and permeable in southwest Nigeria than elsewhere. Every place is potentially an intersection point between the world of humanity and the world of the Orishas; one may meet a spirit on the road without realizing what it is. Every object, whether by virtue of its composition, appearance, or purpose, can be drawn into a sacred context and imbued with additional meaning. These meanings are not fixed, but take an active role in the narratives constructed by worshippers and practitioners. One might think that taboos and prohibitions would abound, affixed to the simplest gestures and activities, and this would not be entirely inaccurate.

Many of the Orisha are earthbound spirits. One respondent indicated that they had "...gone into the ground," and no longer journey to heaven (personal communication, May 2012). However, the Orishas can, and do, travel-even across oceans. This same respondent said of Osun: "Osun is a child of the sea. She tore free of her mother's womb and became the source of all the rivers that run with cool water. You can go to any river and find Osun" (personal communication, January 2013). This story is likely a modern interpretation. Osun was at one point a relatively localized deity, bound to the river that bears her name. Osun is worshipped globally now, from New York to Rio, and devotees make offerings in ceremony on the banks of rivers 
with many names. What does this mean? It is common for new powers to be ascribed to spirits, in accordance with the circumstances of their manifestation in different contexts; consider the various appearances of the Virgin Mother.

Worshipers, initiates, and priests all indicate that specific human problems (e.g., related to finances, lovers, family, work, etc.) are best resolved by spirits that are associated with those domains via a complex network of associations and narratives (personal communication, 2011-2012). Ogun, for example, is considered by Yoruba Nigerians to safeguard road travel on account of his association with all things iron-including, apparently, cars..$^{55}$ As the world expands, so too do the roles of the Orishas; they navigate the turbulent rivers of changing meaning more adeptly than many human communities. In many ways, we find them waiting at the crossroads of past and present, already dressed in the finery of the day. Now, Ogun can be found wearing army fatigue and carrying an assault rifle, marching alongside the soldier; Osun can be found dressed for a night on the town, both seductive and fierce. Change is important to practitioners of Ifa/Orisha. While there are many elements of worship that are timeless and universal, it is important that the traditions reflect the world rather than stand apart from it. Joseph M. Murphy (2001) writes: 55 Robert G. Armstrong (1997:29) writes: "[i]n 1974, for exam-
ple, the drivers of the Ibadan University Motor Transport
system performed a sacrifice to Ögún in the presence of the
Vice-Chancellor and a dozen or so of the other high officials
of the University. One of the drivers...was a particularly en-
thusiastic participant in the dances that followed the sacrifice
of a dog."
Ochún is not what she seems to be. Behind the fan, beneath the surface of the waters, there is always another Ochún...The meaning of symbols rests, of course, on social conditions that make them intersubjectively understandable. As these social conditions change so too do the meanings associated with the symbols and thus their ability to represent social and experiential categories. (p. 96-97)

An important element of religious belief is time. In monotheistic traditions, time can be divided into a number of periods: the mythic pre-historical (e.g., Genesis), the historical, the present, and a mythic future (e.g., Revelations). The progression from one period to another is typically perceived as linear, despite the recurrence of certain themes. Younger religions, if derived from older parent traditions, generally appropriate this narrative and reinterpret it, assigning new values and meanings to the most relevant symbols and altogether discarding or transforming others. Both Hinduism and Buddhism are patterned cyclically, while the monotheistic religions are considered to posit a terminus. Time works quite differently in the Ifa/Orisha tradition.

To outsiders conditioned to think linearly about the greater narrative of a religious system, it may seem that African traditions are left behind. While many belief systems also feature a prophetic or mythic future, ${ }^{56}$

${ }_{56}$ As, for example, the blended Christian-indigenous North American Ghost Dance religion founded by Wodziwob and later represented by its prophet, Jack Wilson. Alice Beck Kehoe (2006:7-9) writes: "[t]his was a complete religion and a continuing power rooted in the eternal Father 'Ghost Dance' is the name usually applied to Jack Wilson's religion, because the prophet foresaw the resurrection religion, because the prophet foresaw the resurrection
of the recently dead with the hoped for renewal of the earth." the apocalyptic narrative is not emphasized by non-Western indigenous traditions. In contrast, the emphasis is on the present and immediate future, on frames of time. These frames do not bridge the past and present in the same way that a recitation of the Gospels or Qur'an does during a sermon; in that case the past is recalled to reinforce the significance of the present as a moment within a narrative unfolding towards a promised terminus. This is more pronounced in millenarian movements based in monotheism, including certain Protestant denominations that focus on an apocalyptic event. The present derives meaning and significance from a projected future, when the fundamental premises of the religion will be proven true.

K. Noel Amherd (2010:124) approaches this subject through language: "time is not water spiraling down a drain unattainably lost only to be represented through historiographic chronology... In this multitext, a person ascends, descends, traverses, reverses, and changes course, constantly relocating within realms nested inside each other, but remaining parts of a total whole." Amherd (2010:125) goes on to say that while English "foregrounds an object's boundedness as a thing that remains through time and space," Yoruba verbs are "poly-temporal" and "modify both time and manifesting" so that while one might say in English it is dark, in Yoruba one might say "S/he/it darks/ed." In a sense, darkness becomes a condition of manifesting, a state experienced by the subject as opposed to a static adjective or descriptor. Amherd (2010) explains the significance of this temporality here: [u]nlike a Western, Abrahamic-infused conception of "heaven," which implies both a separation through time and space from this world, as if one could travel far enough and long enough into space to eventually arrive at heaven's gates, the İsèse idea keeps these realms as a nested whole allowing for movement amidst the entanglement. (p. 130)

This "entanglement" is a matrix of "nested" and interrelated narratives that react to conditions in the present-as, for example, when a babalawo is asked by a client to consult the $\mathrm{Odu}$ on his or her behalf. In the monotheistic traditions, the past-even if it is mytho-historical-is still historical, a point that can no longer be recovered and that exists only in narrative form. In contrast, the mythic past of the Orishas is constantly reenacted in the present. Familiar narratives constellate around compatible associations and bind the timeless to the changeful. When the change is drastic, the symbolic framework of the system adapts, retelling its stories to accommodate new meanings and new experiences. ${ }^{57}$ This may seem like a chicken-and-egg problem: if the Orishas change in response to circumstance and experience, then it stands to reason that they must be products of a collective, cultural imagination, given enough flexibility to

${ }^{57}$ Osun, among the popular of Orishas on both sides of the Atlantic, is particularly adaptable (perhaps unsurpristhe Atlantic, is particularly adaptable (perhaps unsurpris-
ing for a spirit associated with water). Ysamur Flores-Peña
(2001:123) writes on the altars worshippers and practitioners
keep to Ochún; she writes: "[t]he goddess was no longer keep to Ochún; she writes: "[t]he goddess was no longer confined to a river in Africa but extended her influence to
all the rivers in the world...No longer confined to a town or geographic area, which directed and controlled her cult, she moved to new domain areas... But what happens when the ers? American society fell head over heels for the goddess. Her actions empowered new Lucumi worshipers in America, providing a paradigm of assertiveness at home and in the workplace." 
survive even the most drastic changes imposed on the group that is united by those beliefs. ${ }^{58}$

Practitioners obviously do not interpret the Orishas in that way. An answer to the question of how they address the changefulness of their own belief system came in a roundabout way from their answer to my concerns about being an oyinbo trying to learn Ifa:

This will always be the Orishas' home. But the world is far larger than our ancestors believed. The Orishas have always known. It is not that we brought them to other places, the way it is said. We found them waiting for us. You did not find Ifá here; it was Ifá that brought you here (personal communication, May 2012)

Practitioners do not see themselves as originating narratives-the world's stories are encoded in the world itself, in the living experience of every human being. Rather, practitioners see themselves as generating, or regenerating, a matrix of narratives that they participate in. ${ }^{59}$ They are actors on the same stage as the spirits and deities they worship, and time becomes just another element in the story, measured in intervals between the prediction and its manifestation, between the sacrifice and its return. Intermingled with these exchanges are the conflicts, dilemmas, and experiences that con-

$\overline{{ }^{58} \text { Durkheim, naturally, would entirely agree with this point, as }}$ would Marcel Mauss.

59 To bring in Robert Prus, these narratives are essentially life-worlds. Participants use Ifa/Orisha to actively construct and perpetually reshape these worlds accordingly as social mean-
ing, changing circumstances, and necessity make necessary. That they are able to do so without compromising the integrity of their engagement is testament to how accessible, adaptable, and relevant the Orishas are to those who honor them, whether by tradition, choice, or both. stitute human life around the world. Embedded in these experiences are associative clues that connect to an active pantheon of root metaphors that will, and do, respond to the ritualized actions of their devotees. They make their influence known in countless ways, speaking through the people, objects, and circumstances that fall under their purview. New layers of experience represent new means of expression; the mythic does not need to be reinterpreted or recreated. Instead, new modalities are created to represent experiences that are both precedent for new iterations and echoes of an ongoing dialogue between the world of humankind and the world of the spirits.

\section{Conclusion}

There is a good deal of tension between the Abrahamic faiths and Ifa/Orisha traditions in Nigeria. While they are not persecuted, one need only look at the overwhelming number of Protestant initiatives and "Crusades" to realize that Christianity (much of it based in, and originating from, Nigerians) is aggressively pursuing an agenda of conversion. Islam, initially tolerant of other ethno-indigenous practices during the Sokoto Caliphate, is now shifting towards intolerance. These are the extremes of tension, active when an exclusionist religious system interacts with indigenous traditions. There are many other historical and cultural factors involved; for example, Christianity is associated with the West, and the West, in turn, with modernization, industrialization, and globalization. These are socio-historical matrices that dramatically affect local cultures and impact the creation and interpretation of reli- gious narratives. Religions (Yoruba traditions are no exception) have their own ways of narrating history that may not accord with other versions of the story.

The Yoruba mythology is playful, remarkably human, and at times bitterly harsh. The transcendent, embedded in the movement of a history towards an inevitable and divinely ordained end, is found elsewhere in the immense corpus of orature related to Ifa/Orisha. Non-practitioners may find it difficult to locate the transcendent; not only because it is hidden from view but because it is seen through a lens that is specific to those who experience it firsthand. This experience is shaped by how the tradition is disseminated throughout the community. The narratives generated by those who became devotees through conversion are very different from those generated by individuals raised into a belief system by their families; and both are different from those generated by individuals who receive a calling-as many do, who choose to become advanced practitioners of Yoruba traditions.

In the spiritual marketplace, many religions are evaluated on the basis of accessibility. One Christian Nigerian respondent said: "Why are these spirits even necessary? I know what they say: God is distant, and the only way you can reach Him is through these spirits. But, they are not all good. I don't need them. When I pray, I can feel God in my heart" (personal communication, April 2013). Christianity is an accessible religion; while it has many esoteric elements of its own, the promise of salvation and heavenly reward fundamental to the system is available to all who accept as true the major premises of the faith. Ifa/Orisha is somewhat different. While belief in the Orishas is open to all, the Orishas are not obligated to respond to those who do not actively participate in their worship (personal communication, October 2011). They are approached in very specific ways and through particular offerings. If an individual requires their assistance or blessing outside of a ritual context, there are other means-through talismans, herbs, and charms that essentially serve as mobile beacons capable of attracting the spirit in question. Still, to many-especially in the modern worldsuch fetishes represent ignorance and superstition. Is it not simply more effective to believe that a sincere prayer will accomplish the same result? Similarly, the knowledge required to properly petition the Orishas represents another barrier to accessibility that is difficult to surmount for outsiders and foreigners to the tradition.

Another source of tension is translation, in both the literal sense (much of the music of Yoruba is lost in English renditions, including puns, wordplay, and the artistry of the composition) and in the symbolic sense. Reducing deities to common denominators is a generally feeble attempt to strip an aggregate of conceptual associations (i.e., a deity) and reduce it to its original archetypal qualities-in the process stripping it of its history, distinction, and cultural relevance. This is not always the case in syncretic religions, nor with African traditions in the Caribbean and Americas. On the contrary, many Orishas have expanded their roles, adopting new personas to address a multiethnic congregation of devotees. 
In the global spiritual marketplace, foreigners to the traditions also evaluate them on the basis of whether or not they are compatible with established narratives and systems of belief. Unfortunately, this subjects a given tradition to the "pick-and-choose" approach, a decidedly privileged and consumerist attitude towards religion. Traditional practitioners do not have the luxury of deciding whether or not to believe in a particular premise of their faith; to do so would invalidate the faith entirely. The Western spiritual consumer, however, is not restricted in the same way, particularly in the United States. He or she does not feel obligated to preserve the whole at the expense of accepting an unpleasant or possibly offensive aspect of the tradition. Instead, the latter can be abandoned and the remaining fragment juxtaposed to more palatable paradigms of practice. New religions are created out of this individualized habit of practice, disseminated through charismatic representatives, prophets, intellectuals, and through a universe of narratives composed by participants and practitioners. The question remains, however: what becomes of older forms of the tradition? Will they appear only in the records of former observers and participants, otherwise lost in their active form? Or, will they be recycled piecemeal, incorporated into new models better suited to modern life? Carrette and King (2005:85) offer a grim prediction on this note: "[a]s long as spirituality operates according to the dictations of global capitalism it will continue to contribute to the breaking up of traditional communities and the undermining of older, indigenous forms of life around the world." In the next sentence, however, they offer a possible solution: "[c]apitalist spirituality, however, can be overcome by consideration of the forgotten social dimensions...by rescuing and developing alternative models of social justice, and by contesting the corporatization and privatization exemplified in such contemporary forms of spirituality" (Carrette and King 2005:85).

Carrette and King, in emphasizing the social obligations intrinsic to many indigenous spiritual traditions, recall both Durkheim and Mauss. If religion and the sacred are products of sustained engagement with a certain collective or community-united by common belief, mythology, experience, language, et cetera-it stands to reason that the fragmentation of the community would necessarily lead to the fragmentation of the religion. ${ }^{60}$ On the other hand, if a formerly local, tribal, or inter-tribal religious system becomes transnational, affecting the life-worlds of communities around the world, what becomes of it then? ${ }^{61} \mathrm{How}$ does a religion meet the needs of people so radically disparate from one another? How do different cultural communities use the language of shared practice to negotiate an exchange that will strengthen rather than weaken their individual and shared beliefs? Both Christianity and Islam

$\overline{60}$ Remnants may exist, of the sort recorded by Frazer in The Golden Bough; superstitions and legends that once belonged to a living matrix of belief and ideation. These vestigial echoes are not properly called religions in the active, social sense. They are fragments. Even if juxtaposed, it is unlikely that the composite reconstruction will command any of the power or authority enjoyed by the earlier system. Such is often the fate from the Gaelic to the Egyptian, in an attempt to recreate an allegedly universal system.

${ }^{61}$ Durkheim (1995:345) writes: "[h]ence it is man who makes his gods, one can say, or at least, it is man who makes them endure; but at the same time, it is through them that he himsel endures." are seen to use homogeneity to accomplish this purpose:

Preachers and imams both want us to be the same. Everything the same. Same god, same church, same prayer. The Orishas, they are different as we are different. It is better for the world that we are different. Why now would this god have created everyone differently if we were meant to be the same? (personal communication, September 2012)

Ifa/Orisha, in contrast, embraces diversity as a source of narrative, ideological, and spiritual strength. Local spirits may be overshadowed by the major Orishas in the mixed pantheons of belief systems on both sides of the Atlantic, but they stand a greater chance of survival if some role can be found for them in both new and ongoing narratives of collective practice.

Ifa/Orisha in the Diaspora is not necessarily in need of rescuing; there are many who actively promote the preservation of older and more traditional styles of worship, from Oyo Tunji in South Carolina to basement peristyles in Haitian communities in New York City. Unfortunately, the case in Nigeria is different. Nigeria is crippled by corruption, dysfunctional infrastructure, ethnic violence, andsince 2008-plagued by militant Islamist groups in the north and excessively brutal retaliations by the country's own military. Nonetheless, Nigeria is racing towards modernity, funding scientific projects ranging from nanotechnology to innovations in sustainable agriculture. In an effort to compete, there is an implicit prioritization of intellectual resources that does not include the promotion of the country's spiritual heritage. Indeed, that heritage is often perceived as backwards, steeped in ignorance, and obstructive to the pace of development. The dominant narrative of progress is at times dismissive or explicitly hostile towards indigenous religious traditions, but there are many advocates of Ifa/Orisha, in Nigeria and abroad, that recognize the value of a philosophical religion based on inclusivity, worldly spirituality, and an adaptable, diverse, and expansive mythology. Their stories, affirmations, and perspectives will continue to support communities that honor and invoke the Orishas; in return, the Orishas will lend themselves to as many stories as there are individuals to tell them.

One respondent said:

In the West, people no longer worship Zeus, Odin, or any of the old gods that people believed in. The same will happen here in Africa. No one will worship Ogun or Shango anymore. Just like no one believes that it is Zeus who hurls lightning bolts, no one will believe that Shoponna causes smallpox or HIV. (personal communication, February 2013)

An initiate replied:

It is true that we are now informed as to the causes of things. But, the spirits hide themselves behind the causes of things. It is Ogun in the heart of a man who defends his people. It is Esu hidden behind the circumstances that cause a bridge to collapse when a cursed man walks over it. The world comes alive when you believe. It is only a dead thing, filled with suffering, when you interpret it mechanically. (personal communication, February 2013) 


\section{References}

Abimbola, Wande. 1976. Ifá: An Exposition of Ifá Literary Corpus. Ibadan: Oxford University Press.

Abimbola, Wande. 1977. Ifá Divination Poetry. New York: NOK Publishers.

Adelakun, Abimbola. 2010. "Derided, Misrepresented, Ifa Priests Tell Their Stories." The Punch News. Retrieved September 16, 2014 (http://egregores.blogspot.com/2010/05/such-is-relationship-between-africans.html).

Amherd, Noel K. 2010. Reciting Ifá: Identity, Difference, and Heterogeneity. Trenton, NJ: Africa World Press.

Armstrong, Robert G. 1997. "The Etymology of the Word 'Ogun."' Pp. 29-38 in Africa's Ogun: Old World and New, edited by Sandra T. Barnes. Indianapolis: Indiana State University.

Barnes, Sandra T. 1997. "Introduction: The Many Faces of Ogun." Pp. 1-26 in Africa's Ogun: Old World and New, edited by Sandra T. Barnes. Indianapolis: Indiana State University.

Barnes, Sandra T. and Paula Girshick Ben-Amos. 1997. “Ogun, the Empire Builder." Pp. 39-64 in Africa's Ogun: Old World and New, edited by Sandra T. Barnes. Indianapolis: Indiana State University.

Bascom, William. 1969. Ifá Divination. Communication Between Gods and Men in West Africa. Bloomington, London: Indiana University Press.

Bascom, William. 1980. Sixteen Cowries. Yoruba Divination From Africa to the New World. Bloomington: Indiana University Press.

Brown, Karen McCarthy. 1997. "Systematic Remembering, Systematic Forgetting: Ogou in Haiti." Pp. $65-89$ in Africa's Ogun: Old World and New, edited by Sandra T. Barnes. Indianapolis: Indiana State University.

Carrette, Jeremy and Richard King. 2005. Selling Spirituality: The Silent Takeover of Religion. London: Routledge.

Cox, James L. 2001. "Missionaries, the Phenomenology of Religion, and 'Re-Presenting' $19^{\text {th }}$ Century African Religion:
A Case Study of Peter McKenzie's 'Hail Orisha!'” Journal of Religion in Africa 31(3):336-353.

Drewal, Margaret Thompson. 1997. “Dancing for Ògun in Yorubaland and Brazil." Pp. 199-234 in Africa's Ogun: Old World and New, edited by Sandra T. Barnes. Indianapolis: Indiana State University.

Durkheim, Emile. 1995. The Elementary Forms of Religious Life. New York: The Free Press.

Eleburuibon, Ifayemi. 1989. The Adventures of Obatala. Part 1. Oyo State: A. P. I. Production

Eleburuibon, Ifayemi. 1998. The Adventures of Obatala. Part 2. Lynwood, CA: Ara Ifa Publishing.

Eleburuibon, Ifayemi. 2004. Ifá: The Custodian of Destiny. Ibadan: Penthouse Publication

Fama, Chief. 1994. Sixteen Mythological Stories of Ifá. San Bernardino, CA: Ile Qrunmila Communications.

Flores-Peña, Ysamur. 2001. “Overflowing the Beauty: Ochún Altar in Lucumí Aesthetic." Pp. 113-127 in Osun Across the Waters: A Yoruba Goddess in Africa and the Americas, edited by Mei-Mei Sanford, Joseph Murphy. Bloomington: Indiana University Press.

Hale, Lindsay. 2001. “Mama Oxum: Reflections of Gender and Sexuality in Brasilian Umbanda." Pp. 213-229 in Osun Across the Waters: A Yoruba Goddess in Africa and the Americas, edited by Mei-Mei Sanford, Joseph Murphy. Bloomington: Indiana University Press.

Kehoe, Alice Beck. 2006. The Ghost Dance: Ethnohistory and Revitalization. Long Grove, IL: Waveland Press.

Marriott, McKim, (ed.). 1955. Village India: Studies in the Little Community. Chicago: University of Chicago Press.

Mauss, Marcel. 2001. A General Theory of Magic. London: Routledge.
McKenzie, Peter. 1976. "Yoruba Orisa Cults: Some Marginal Notes Concerning Their Cosmology and Concepts of Deity." Journal of Religion in Africa 8(3):189-207.

Murphy, Joseph M. 2001. "Yéyé Cachita: Ochún in a Cuban Mirror." Pp. 87-101 in Osun Across the Waters: A Yoruba Goddess in Africa and the Americas, edited by Mei-Mei Sanford, Joseph Murphy. Bloomington: Indiana University Press.

Nicklas, Michael A. 1990. “Mythology, Knowledge, and Power: An Examination of Social Forces in Brazil and the Emergence of Umbanda." Folklore Forum 23(1/2):85-97.

Peel, J.D.Y. 1997. “A Comparative Analysis of Ogun in Precolonial Yorubaland." Pp. 263-289 in Africa's Ogun: Old World and New, edited by Sandra T. Barnes. Indianapolis: Indiana State University.

Pemberton, John. 1997. "The Dreadful God and Divine King." Pp. 105-146 in Osun Across the Waters: A Yoruba Goddess in Africa and the Americas, edited by Mei-Mei Sanford, Joseph Murphy. Bloomington: Indiana University Press.
Probst, Peter. 2004. "Keeping the Goddess Alive: Performing Culture and Remembering the Past in Oshogbo, Nigeria." Social Analysis 48(1):33-54.

Prus, Robert. 1997. Subcultural Mosaics and Intersubjective Realities. An Ethnographic Research Agenda for Pragmatizing the Social Sciences. Albany: State University of New York Press.

Ryan, Patrick J. 1980. “'Arise, O God!' The Problem of 'Gods' in West Africa." Journal of Religion in Africa 11(3):161-171.

Walker, Sheila S. 1980. "African Gods in the Americas: The Black Religious Continuum." The Black Scholar 11(8):25-36.

Weber, Max. 1946. From Max Weber: Essays in Sociology. Edited by Hans Gerth, C. Wright Mills. New York: Oxford University Press.

Weber, Max. 1963. The Sociology of Religion. Boston: Beacon Press. 